\title{
Unprecedented wind erosion and perturbation of surface geochemistry marks the Anthropocene in Australia
}

\author{
Samuel K. Marx, ${ }^{1,2}$ Hamish A. McGowan, ${ }^{3}$ Balz S. Kamber, ${ }^{4}$ Jon M. Knight, ${ }^{5}$ \\ John Denholm, ${ }^{6}$ and Atun Zawadzki ${ }^{7}$ \\ Received 22 August 2013; revised 24 November 2013; accepted 26 November 2013; published 14 January 2014.
}

[1] Australia, the last continent to undergo industrial development, is an ideal environment in which to quantify the magnitude of human-induced environmental change during the Anthropocene because its entire agricultural and industrial history has occurred within this period. Analysis of an alpine peat mire showed that rapid industrial and agricultural development (both pastoral and cropping) over the past 200 years has resulted in significant environmental change in Australia. Beginning in the 1880s, rates of wind erosion and metal enrichment were up to 10 and 30 times that of background natural conditions, respectively. Increased dust deposition and an expansion in dust source areas were found to map the progression of European farming across the continent, while dust deposition pulses in the mire matched known land degradation events. After 1990 dust deposition decreased, returning to pre-1880 rates. This was attributed to three factors: net soil loss following more than a century of agricultural activity, increased environmental awareness and soil conservation, and changing windiness. Metal enrichment in the mire reached approximately 2 times natural background accumulation rates by the 1980s as Australia's mining industry expanded. However, metal enrichment continued to increase after the 1980s reaching an average of $\sim 5$ times background rates by 2006 and reflecting increased mineral resource development in Australia. Collectively, the results show that changes to Australia's geochemical and sedimentary systems, as a result of agricultural and industrial development, have profoundly changed the Australian environment during the past two centuries.

Citation: Marx, S. K., H. A. McGowan, B. S. Kamber, J. M. Knight, J. Denholm, and A. Zawadzki (2014), Unprecedented wind erosion and perturbation of surface geochemistry marks the Anthropocene in Australia, J. Geophys. Res. Earth Surf., 119, 45-61, doi:10.1002/2013JF002948.

\section{Introduction}

[2] The term Anthropocene was coined to encompass the geologic epoch of human-induced change in Earth's systems, driven by industrialization, agricultural expansion, technological advances, and population growth since the late eighteenth

\footnotetext{
${ }^{1}$ GeoQuEST Research Centre, School of Earth and Environmental Sciences, University of Wollongong, Wollongong, New South Wales, Australia.

${ }^{2}$ Wollongong Isotope Geochronology Laboratory, School of Earth and Environmental Sciences, University of Wollongong, Wollongong, New South Wales, Australia.

${ }^{3}$ Climate Research Group, School of Geography, Planning and Environmental Management, University of Queensland, Brisbane, Queensland, Australia.

${ }^{4}$ Department of Geology, School of Natural Sciences, Trinity College Dublin, Dublin, Ireland.

${ }^{5}$ Australian Rivers Institute, School of Environment, Planning and Architecture, Griffith University, Nathan, Queensland, Australia.

${ }^{6}$ Scientific Services, Snowy Hydro Limited, Cooma, New South Wales, Australia.

${ }^{7}$ Institute for Environmental Research, Australian Nuclear Science and Technology Organisation, Sydney, New South Wales, Australia.

Corresponding author: S. K. Marx, Wollongong Isotope Geochronology Laboratory, School of Earth and Environmental Sciences, University of Wollongong, Wollongong, NSW 2522, Australia. (smarx@uow.edu.au)

(C)2013. American Geophysical Union. All Rights Reserved. 2169-9003/14/10.1002/2013JF002948
}

century [Crutzen, 2002]. It is manifest as a perturbation of the Earth's surficial geochemistry through emissions of industrial waste products, including greenhouse gases [e.g., Forster et al., 2007], radioactive material [e.g., Kinoshita et al., 2011], and toxic metals [e.g., Brännvall et al., 1999] and compounds [e.g., Lavin et al., 2012]. Agricultural development (both cropping and pastoralism) has resulted in marked global landscape change. This has included vegetation clearance and altered hydroclimatic regimes and often warmer and drier climates [Foley et al., 2005; McAlpine et al., 2009]. These factors have been linked to enhanced soil erosion by both wind and water and lower soil productivity [Lal, 2010; Montgomery, 2007b; Mulitza et al., 2010].

[3] While the Anthropocene is generally accepted to encompass the period of extensive human-induced change to Earth surface processes since the Industrial Revolution, human activity and its impacts extend into prehistory. Perturbation of metals in the environment and the development of agriculture has been traced in sedimentary deposits in Europe, Asia, Africa, and North and South America from the middle to late Holocene (circa 6000-3000 B.P.) [e.g., Axtell et al., 2002; Brännvall et al., 1999; Cooke et al., 2009; Lee et al., 2008; Lejju et al., 2005; McMichael et al., 2012]. In some cases, soil loss was so severe it is thought to have played a major role in 


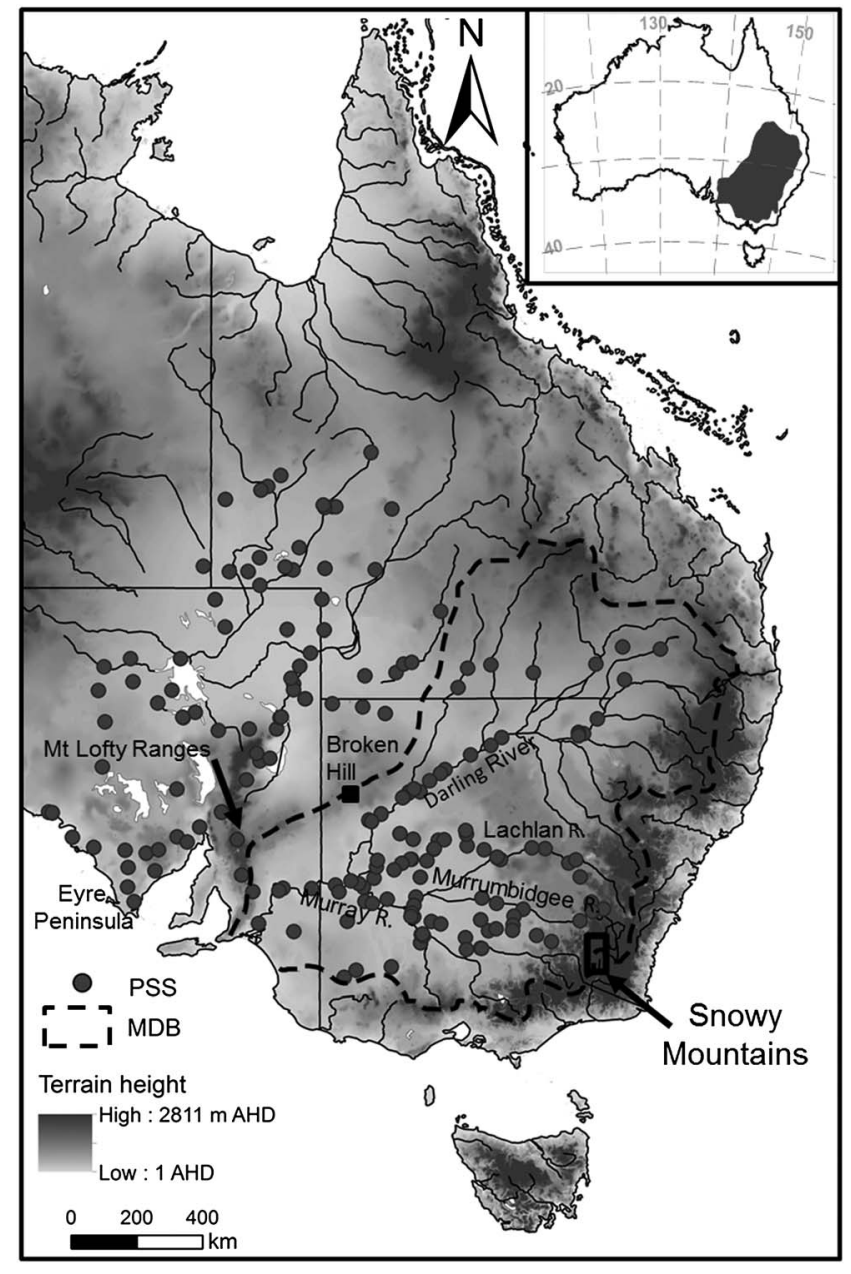

Figure 1. Location map of eastern and central Australia showing the Snowy Mountains, the Murray-Darling Basin (MDB), and the locations from where potential dust source sediments (PSS) were collected. The inset shows the position of the MDB in southeastern Australia.

the demise of civilizations [see Montgomery, 2007a]. Even within this long history, the scale of anthropogenic change over the last 200 years is regarded as considerably more significant [Crutzen, 2002; Wolfe et al., 2013]. However, the impact of the Anthropocene is potentially more marked in Australia as it is one of the few settings in which the onset of the Anthropocene is unambiguous, coinciding with European settlement that occurred from 1788 .

[4] Prior to 1788, Australia's indigenous population lived a largely hunter-gather existence in small populations for 40,000-60,000 years [Bowler et al., 2003; Rasmussen et al., 2011; Roberts et al., 1994]. Agricultural activity during that time is believed to have involved minimal pastoral management of native pastures, using fire [Jones, 1969; Mooney et al., 2011]. European settlement transformed Australia's environment with extensive clearing of native vegetation for agricultural production, primarily pastoralism and, to a lesser extent, cropping [McAlpine et al., 2009]. Australia's considerable mineral resources were also developed from the mid-1800s, with metal production (mining and processing) and coal mining and combustion continuing unabated to the present [Martin et al., 1993; Mudd, 2007]. Consequently, in the span of the Anthropocene, the Australia landscape is likely to have been transformed by extensive perturbation of its surface geochemistry combined with significant soil erosion, both by water and wind. The scale of these changes has not been broadly quantified, with most existing studies limited to industrial or urban sites or to specific river catchments [Chiaradia et al., 1997; Connor and Thomas, 2003; Fanning, 1999; Harrison et al., 2003; Olley and Wasson, 2003; Wasson and Galloway, 1986].

[5] Studies of human-induced erosion have largely focused on water erosion, which is more apparent in the landscape due to formation of quintessential erosion features, including rills and gullies, which can be highly visible. Furthermore, fluvial erosion rates can be estimated directly from incision rates, river sediment loads and rates of alluvium deposition in channels, estuaries, and deltas [e.g., Hewawasam et al., 2003; Montgomery, 2007b; Olley and Wasson, 2003]. In comparison, wind erosion is generally harder to identify and quantify as significant erosion can leave very little obvious trace in the landscape. Typically, deposition of dust results in extremely thin layers spread over large areas, e.g., tens of thousands of square kilometers [McTainsh, 1989]. Consequently, despite the predominance of research on water erosion, wind erosion is regarded as the most significant geomorphic agent in many arid and semiarid environments [Goudie, 1978; Goudie and Middleton, 2006; Pye, 1987]. This is particularly so for Australia, which is the most arid inhabited continent [McTainsh, 1989].

[6] Advances in geochemical fingerprinting over the last 10 years have enabled detailed studies of rates and sources of dust deposition in geological repositories such as ice, peat deposits, and lakes [Gabrielli et al., 2010; Le Roux et al., 2012; Marx et al., 2009; Shotyk et al., 1998]. Recent studies in which geochemical fingerprinting has been applied to dust in cores extracted from geologic repositories upwind of major semiarid agricultural regions have shown marked increases in dust deposition associated with the onset of industrial agriculture [McConnell et al., 2007; Mulitza et al., 2010; Neff et al., 2008]. These studies highlight the impact of agriculture as a driver of significant soil loss via wind erosion.

[7] This paper examines the chronology of landscape change in Australia over the last 300 years. Rates of soil loss are compared before and after European settlement using dust deposition in an alpine peat mire in the Snowy Mountains, New South Wales. In addition, we re-examine the results of a previous study of patterns of toxic metal accumulation in the mire [Marx et al., 2010]. Combined, the dust record and metal patterns provide a picture of the extent of environmental change in Australia during the Anthropocene. The paper builds on previous work, that examined the palaeorecord of dust deposition over the last 6500 years at the site [Marx et al., 2011], by presenting a high-resolution analysis and interpretation focused on Australia's Anthropocene.

\section{Methods and Approach}

\subsection{Regional Setting}

[8] The Snowy Mountains, located in southeastern Australia, form part of the Great Dividing Range, a $>4000 \mathrm{~km}$ mountain chain stretching along Australia's east coast (Figure 1). 
The Snowy Mountains, with peaks reaching above $2000 \mathrm{~m}$ (Australian Height Datum), are part of the Palaeozoic Lachlan Fold Belt, consisting of granitic and sedimentary rocks with minor metamorphic and other volcanic rocks. They have a cool/montane climate, with snow cover usual for 3-6 months annually. Seasonal average temperatures vary from $15^{\circ} \mathrm{C}$ (summer) to $-1^{\circ} \mathrm{C}$ (winter), with annual precipitation $\sim 2000 \mathrm{~mm}$ and prevailing westerly quarter winds in all seasons. Vegetation above the tree line $(1800 \mathrm{~m})$ comprises alpine herb fields and heath, while extensive peat mires, vegetated by Sphagnum moss species, blanket the landscape [Costin, 1972; Martin, 1999].

[9] The Snowy Mountains form part the eastern boundary of the Murray-Darling Basin (MDB), a large sedimentary ba$\sin \left(\sim 1\right.$ million $\left.\mathrm{km}^{2}\right)$ covering $1 / 7$ of the Australian continent. Much of the MDB is semiarid, with rainfall decreasing westward. The basin is characterized by two major east-west flowing river systems, the Darling and Murray Rivers (Figure 1). Two additionally significant rivers, the Lachlan and Murrumbidgee, flow westward between them. Both the Murray and Murrumbidgee have their headwaters in the Snowy Mountains. The MDB is Australia's most important agricultural region, with both extensive livestock grazing and cropping, contributing $40 \%$ of the nation's agricultural produce. The basin also contains significant mineral resources, including the Broken Hill Mines (Figure 1).

[10] The study site (Figure 1) was a shallow ombrotrophic (rainfall fed) peat mire $\left(-36.463^{\circ}, 148.299^{\circ}\right)$ blanketing an alpine basin within Kosciusko National Park at $1940 \mathrm{~m}$ altitude. The park is now protected but was used for grazing until the mid-1900s. The mire forms part of a more extensive peat mire complex occupying a shallow $\sim 30$ ha alpine basin sloping gently to the north (slope $<1 \%$ ). To the east, the basin was bordered by broad topped peaks rising gently to $2020 \mathrm{~m}$, with extensive block fields mantling the slopes above the mire. To the west, a low drainage divide (1945 m) separated the basin from another extensive peat-filled basin. Peat depths at the site ranged from 0.5 to $1.1 \mathrm{~m}$ in the center to $<0.1 \mathrm{~m}$ at its margins. As a rainfall fed mire, the composition of material deposited in it should broadly reflect the particulate composition of the atmosphere of southeastern Australia, and specifically, the Murray-Darling Basin located upwind of the studied mire.

\subsection{Core Extraction and Analysis}

[11] A $1 \mathrm{~m}$ core was extracted from the mire using a Russian D section type corer, as discussed in Marx et al. [2011]. In the laboratory the core, frozen to preserve its stratigraphy, was shaved into fine segments of between 2 and $5 \mathrm{~mm}$. Each segment was dried in an oven at $60^{\circ} \mathrm{C}$ for $36 \mathrm{~h}$. A subsample of each segment was combusted in a high-temperature oven at $450^{\circ} \mathrm{C}$ for $12 \mathrm{~h}$, volatilizing the organic component of the samples. The mineral component was retained for geochemical analysis.

[12] Trace element composition was analyzed in 79 samples through the core by quadrapole inductively coupled plasma-mass spectrometry on a Thermo X Series11 instrument at Laurentian University, Ontario, Canada, according the procedure of Eggins et al. [1997], with modifications according to Kamber [2009]. Further analytical details and presentation of rock standards are presented in Marx et al. [2011].
[13] Subsamples of dry peat were selected through the top of the core for dating by ${ }^{14} \mathrm{C}$ accelerator mass spectrometry $(n=3)$, at the Waikato Radiocarbon Laboratory, Waikato University, New Zealand, and ${ }^{210} \mathrm{~Pb}(n=7)$ at the Environmental Research Laboratories, Australian Nuclear Science and Technology Organisation, NSW, Australia. Lead-210 dates were undertaken on sediment within the core and were calculated using the constant rate of supply model [Walling et al., 2002]. Lead-210 dating was performed by measuring ${ }^{210} \mathrm{Po}$ activity, the granddaughter of ${ }^{210} \mathrm{~Pb}$ with which it is assumed to be in secular equilibrium. Supported ${ }^{210} \mathrm{~Pb}$ was determined by measuring ${ }^{226} \mathrm{Ra}$, with unsupported ${ }^{210} \mathrm{~Pb}$ calculated from the difference between supported and total ${ }^{210} \mathrm{~Pb}$ activity [Harrison et al., 2003]. Carbon-14 dating was undertaken on pollen concentrate extracted according to van der Kaars [1991] and bulk peat. The two upper most ${ }^{14} \mathrm{C}$ dates were undertaken on pollen concentrate. They contained modern $\mathrm{C}$ and were therefore calibrated with the CALIbomb program using the Wellington data set [Manning and Melhuish, 1994]. The age of the two dates was established by reference to the ${ }^{210} \mathrm{~Pb}$ dates surrounding them and by the timing of metal pollution accumulation in the core [Marx et al., 2010]. The lowermost ${ }^{14} \mathrm{C}$ date was undertaken on bulk peat and calibrated using Oxcal with the ShCal04 data set [McCormac et al., 2004]. This date returned an age significantly older than the ${ }^{210} \mathrm{~Pb}$ dates (by circa 290 years), and we suspect that this was due to mobile carbon within the peat profile, or alternatively that older carbon was incorporated into the mire.

\subsection{Age Model Construction}

[14] An age model was constructed for the top $180 \mathrm{~mm}$ of the core covering the period of interest for this study (the last 300 years) using the two ${ }^{14} \mathrm{C}$ dates obtained on pollen concentrate samples and all the ${ }^{210} \mathrm{~Pb}$ dates. These dates displayed a coherent age/depth relationship, with agreement between the ${ }^{14} \mathrm{C}$ and ${ }^{210} \mathrm{~Pb}$ dates. The age model, previously published in Marx et al. [2010], was constructed by fitting a second order polynomial curve to the age/depth data (Figure 2). This curve explained $>99 \%$ of variance in the age/depth relationship for the top of the core with low residuals ( $0.1-6.7$ years). The timing of changes in metal pollution in the core, as recorded by different ratios of $\mathrm{Pb}$ isotopes reported in Marx et al. [2010], provided an independent chronology that agrees with the age model (Figure 2). For example, lower ${ }^{206} \mathrm{~Pb} /{ }^{204} \mathrm{~Pb}$ ratios resulting from the deposition of less radiogenic $\mathrm{Pb}$ corresponded with the initial onset of $\mathrm{Pb}$ mining in Australia in the late 1840s, while the beginning of $\mathrm{Zn}$ mining was also evident in the core [Marx et al., 2010]. Similarly, onset of $\mathrm{Pb}$ mining at Broken Hill in the 1890 s and the introduction of leaded fuel in the 1930s, both resulted in the deposition of slightly less radiogenic $\mathrm{Pb}$ that corresponded with the ${ }^{210} \mathrm{~Pb}$ and ${ }^{14} \mathrm{C}$ dates (Figure 2).

\subsection{Determining the Dust Content of the Core and Its Provenance}

[15] The core is assumed to comprise sediment from two separate sources; long-range aeolian dust sourced upwind from within Australia's vast semiarid and arid interior, and locally sourced local alluvial/colluvial material. To determine the dust component we separated dust from other 


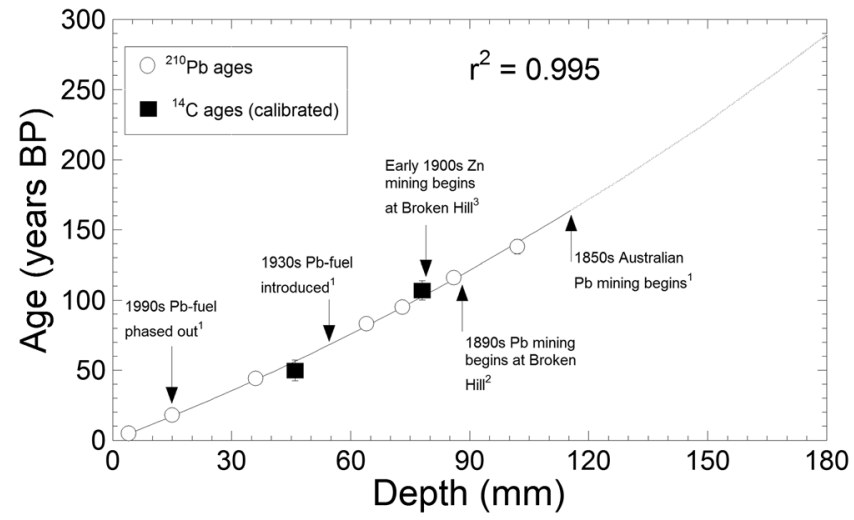

Figure 2. Age/depth relationship for the Snowy mire core [after Marx et al., 2010]. The fitted curve is a second order polynomial function; error bars are combined age model residuals and the 2 sigma dating errors. Arrows show depths where known historical events are recorded by changing metal pollution patterns in the core (see text and Marx et al. [2010]). Superscript 1 is indicated by $\mathrm{Pb}$-isotope ratios. Superscript 2 is indicated by $\mathrm{Pb}$-isotope ratios and $\mathrm{Pb}$ concentrations. Superscript 3 is indicated by $\mathrm{Zn}$ concentrations.

material transported into the mire using its trace element chemistry and a mass balance approach [Marx et al., 2005a]. This approach can also be used to determine dust provenance at a geologic-catchment scale. This is possible because the trace element chemistry of sediments within dust source regions, which in Australia are supplied with sediment by river systems that episodically flow in arid and semiarid inland Australia, reflect the geology in their headwater catchments [Kamber et al., 2005; Marx and Kamber, 2010]. Consequently, different dust source regions have unique trace element fingerprints. For example, the Murray River region has relatively high concentrations of highly to moderately incompatible elements (rare earth elements, Th, and Sc) in comparison to the Darling River [Marx and Kamber, 2010]. A database of the trace element composition of $>200$ samples collected from the major potential dust source regions in Australia was constructed [Marx and Kamber, 2010; Marx et al., 2009]. These were collected as grab samples $(1-3 \mathrm{~cm})$ from surfaces known to supply dust to the airstream, e.g., playa surfaces, dunes, alluvial plains, and channel deposits [Bullard et al., 2011]. Potential source sediments (PSS) were collected broadly from dust source areas across eastern and central Australia [McTainsh et al., 1998; Webb et al., 2006]. This included the MDB, the Lake Eyre Basin in central Australia, the Flinders Ranges, Gawler Region and Eyre Peninsula in South Australia, and the Mulga Lands in central Queensland (Figure 1). Sediments of local Snowy Mountains origin were similarly collected and analyzed [Marx et al., 2011]; these are assumed to be representative of locally eroded and transported material in the Snowy Mountains.

[16] For this study 19 elements were deemed to have behaved conservatively during entrainment, transport, and deposition and post deposition, meaning their relative concentration within core sediments is the same as that of their provenance region. These included the rare earth elements, La, Ce, Pr, Nd, Sm, Eu, Gd, Tb, Dy, and Y, the alkali and earth-alkali metals $\mathrm{Li}, \mathrm{Rb}$, and $\mathrm{Ba}$, the actinoid element $\mathrm{Th}$, the high field strength elements $\mathrm{Nb}, \mathrm{Ta}$, and $\mathrm{Sc}$, and a Group 6, 13, and 14 metal, Ti, Ga, and Sn, respectively (see Marx et al. [2011] for discussion of why these particular trace elements were used).

[17] The concentration of dust deposited in the core along with its most likely provenance region was determined using a mass balance model in which the concentration of trace elements in sediment samples extracted from the core were quantitatively compared with every PSS (equation (1)):

$$
\sum_{D}=\sum_{i=1}^{n}\left|\left(\left(E_{d(i)} * E n\right) / \sum E_{D}\right)-1\right|
$$

where $\Sigma_{D}$ is the degree of match $(0=$ a perfect match $)$ between a dust sample and a PSS. En is the number of trace

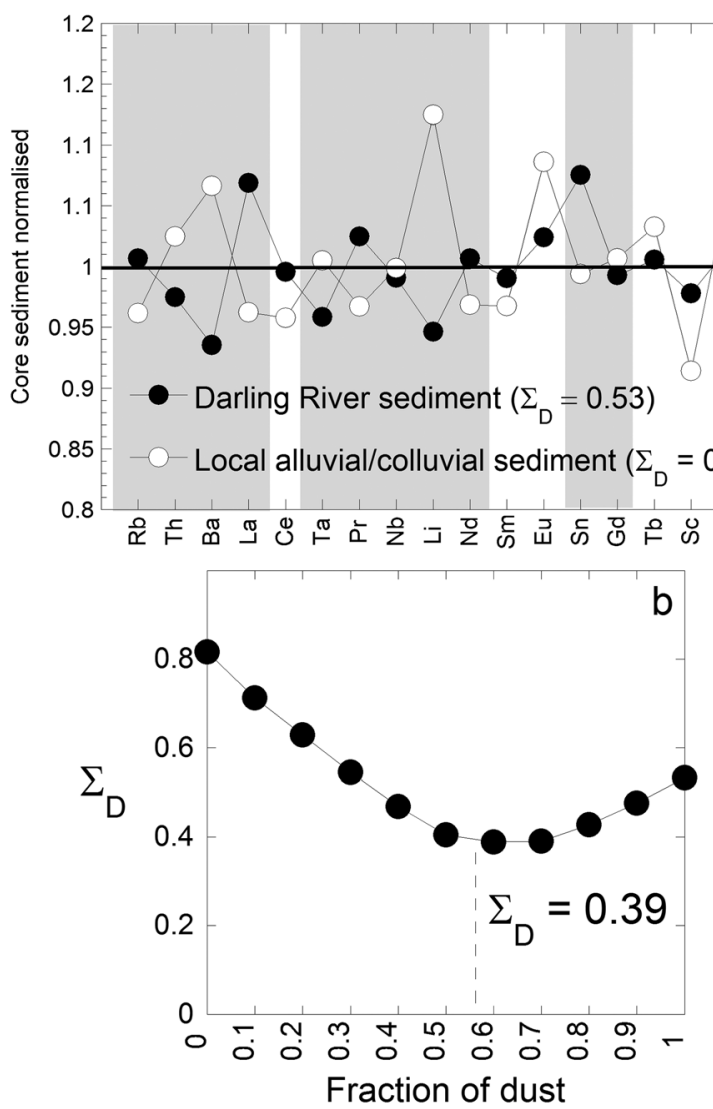

Figure 3. Example plots showing the use of trace elements to model dust content in the mire. (a) Trace element composition of two PSS (a potential dust source sediment from the Darling River and a local Snowy Mountains sediment) normalized against a core sediment from $1.7 \mathrm{~mm}$ depth. Grey bars indicate elements where a binary mixture of the two PSS would yield a better approximation of the chemistry of the core sediment than either individually. (b) A provenance diagram showing the degree to which a binary mixture of the two PSS approximate the chemistry of core sediment. The $x$ axis shows the relative fraction of dust versus local sediment, where 0 equates to $100 \%$ local sediment. The $y$ axis shows the degree of match $\left(\Sigma_{D}\right)$. The minima indicate the best match of the core sediment, i.e., a mixture of 58:42 dust to alluvial sediment. 


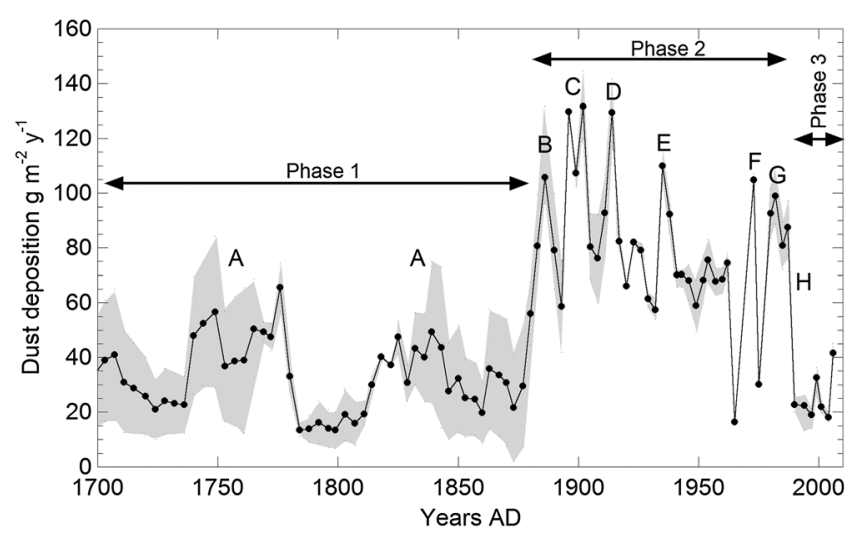

Figure 4. Dust deposition rates in the Snowy mire core plotted from 1700 to 2006. The grey outline shows 2 sigma errors. The letters on the plot refer to $\mathrm{A}=$ dust pulses during the Little Ice Age; $\mathrm{B}=$ the onset of agriculturally induced wind erosion; $\mathrm{C}=$ the Federation Drought; $\mathrm{D}=$ the 1914 drought; $\mathrm{E}=$ the Dust Bowl era; $\mathrm{F}=$ the early 1970s and $\mathrm{G}=1980$ s droughts; and $\mathrm{H}=$ implementation of concerted soil conservation measures.

elements used to determine provenance $(n=19) . E_{d(i)}$ is the normalized difference between the concentration of a particular trace element in the dust to that of a PSS (equation (2)):

$$
E_{d(i)}=\left(\left(E_{\mathrm{pss}(i)} / E_{\mathrm{dust}(i)}\right)+\left(E_{\mathrm{dust}(i)} / E_{\mathrm{pss}(i)}\right)\right) / 2
$$

where the subscripts "pss" and "dust" denote a PSS and dust sample, respectively. $\Sigma E_{D}$ is the sum all the individual $E_{d(i)}$ values (equation (3)):

$$
\sum E_{D}=\sum_{i=1}^{n} E_{d(i)}
$$

[18] Because quartz hosts no trace elements, a correction for the effects of quartz dilution was included in the equation [see Marx et al., 2005a]. This is achieved by calculating the relative concentration of elements in each sample by multiplying $E_{d(i)}$ by the number of elements $(E n)$ and dividing by the sum of normalized differences $\left(\Sigma E_{D}\right.$ equation (1)).

[19] The relative contribution from the two end-member groups (local Snowy Mountains sediment and dust) was separated using a binary mixing model [Marx et al., 2011] which allowed the dust component to be isolated. An example of how this was achieved is shown in Figure 3 for a particular core sediment sample. In Figure 3a, the two closest matching PSS (lowest $\Sigma_{D}$ ) from the two end-member groups (one local Snowy sediment and one sample from the lower Darling River flood plain) are shown normalized against a core sediment from $1.7 \mathrm{~mm}$ depth. Overall the Darling River PSS matched the core sediment more closely than the Snowy sediment, demonstrated by its lower $\sum_{D}$ of 0.53 versus 0.82 . Some elements in the core sediment (those highlighted by grey bars) had intermediate concentrations between the two PSS. Therefore, a binary mixture yielded a better overall $\sum_{D}$ than either PSS individually. This is shown in Figure 3b, where a fraction of 0 dust equals $100 \%$ local sediment. The lowest $\sum_{D}$ value represents the mixture which best approximates the chemistry of core sediment, e.g., a mixture of $58 \%$ dust to $42 \%$ local sediment in this example.

[20] To reduce the possibility that a PSS matches a core sediment sample by chance, the dust component was determined from the average modeled dust component of all PSS samples within 2 standard deviations of the best possible mixture (typically approximately five samples). Because of the spatial affinity in the chemistry of PSS [Kamber et al., 2005; Marx and Kamber, 2010], these were generally of close proximity, e.g., from the same floodplain.

\section{Results}

\subsection{Dust Deposition Rates}

[21] Dust deposition rates during the last 300 years are shown in Figure 4. Deposition rates were calculated by dividing the dust content in each segment of the core by the segment age, based on the derivative of the age model. Two distinct changes are evident in the record: (1) a rapid increase in dust deposition after 1879 (shown as B in Figure 4) and (2) a rapid decrease in deposition after 1989 ( $\mathrm{H}$ in Figure 4). These changes define three phases of deposition: (1) pre-European 1700-1879, (2) agricultural expansion 1880-1989, and (3) agricultural stabilization 1990 to present. Summary statistics for each phase are given in Table 1. During phase 1, two broad pulses in dust deposition occur: 1740 s to 1780 and 1812-1845 (A in Figure 4) (average 48.4 and $40.2 \mathrm{~g} \mathrm{~m}^{-2} \mathrm{yr}^{-1}$, respectively, Table 1). These pulses coincide with the timing of cool phases within the Little Ice Age (LIA) [Hendy et al., 2002]. Average dust deposition rates for the 1700-1879 phase (32.8 and $24.8 \mathrm{~g} \mathrm{~m}^{-2} \mathrm{yr}^{-1}$, including and excluding the LIA pulses, respectively (Table 1)) provide an estimate of natural background wind erosion rates. By comparison, average dust deposition rates during the subsequent European agricultural expansion phase (1880 to 1989) were $80.4 \mathrm{~g} \mathrm{~m}^{-2} \mathrm{yr}^{-1}, 2.5$ times greater (Table 1). Furthermore, pulses of up to $131.7 \mathrm{~g}$ $\mathrm{m}^{-2} \mathrm{yr}^{-1}$ (Table 1 ) in the early 1900 s were 10 times the minimum rates of $\sim 13 \mathrm{~g} \mathrm{~m}^{-2} \mathrm{yr}^{-1}$ in the $1780 \mathrm{~s}$ and $1790 \mathrm{~s}$ (Figure 4). There is also a significant decrease in dust

\begin{tabular}{|c|c|c|c|c|c|c|}
\hline Period & $n$ & $\begin{array}{l}\text { Average Dust Deposition } \\
\text { Rate }\left(\mathrm{g} \mathrm{m}^{-2} \mathrm{yr}^{-1}\right)\end{array}$ & $\begin{array}{l}\text { Dust Deposition Range } \\
\qquad\left(\mathrm{g} \mathrm{m}^{-2} \mathrm{yr}^{-1}\right)\end{array}$ & Standard Error & Trend Slope & $r^{2}$ \\
\hline 1700-1879 including pulses & 47 & 32.8 & $13.3-65.6$ & 1.9 & -0.03 & 0.02 \\
\hline $1700-1879$ excluding pulses & 26 & 24.8 & $13.3-41$ & 1.6 & -0.01 & 0.01 \\
\hline Pulse 1 1740-1780 & 11 & 48.4 & $36.8-65.6$ & 2.7 & - & - \\
\hline Pulse 2 1812-1845 & 9 & 40.2 & $30-49.3$ & 2.2 & - & - \\
\hline $1880-1989$ & 36 & 80.3 & $16.3-131.7$ & 4.1 & -0.26 & 0.10 \\
\hline $1880-2006$ & 43 & 71.4 & $16.3-131.7$ & 4.7 & -0.51 & 0.38 \\
\hline 1990-2006 & 7 & 25.4 & $18.1-41.6$ & 3.2 & 0.65 & 0.18 \\
\hline
\end{tabular}

Table 1. Summary of Results From Analysis of Different Sections of the Dust Deposition Record Identified for the Period 1700 to 2006 


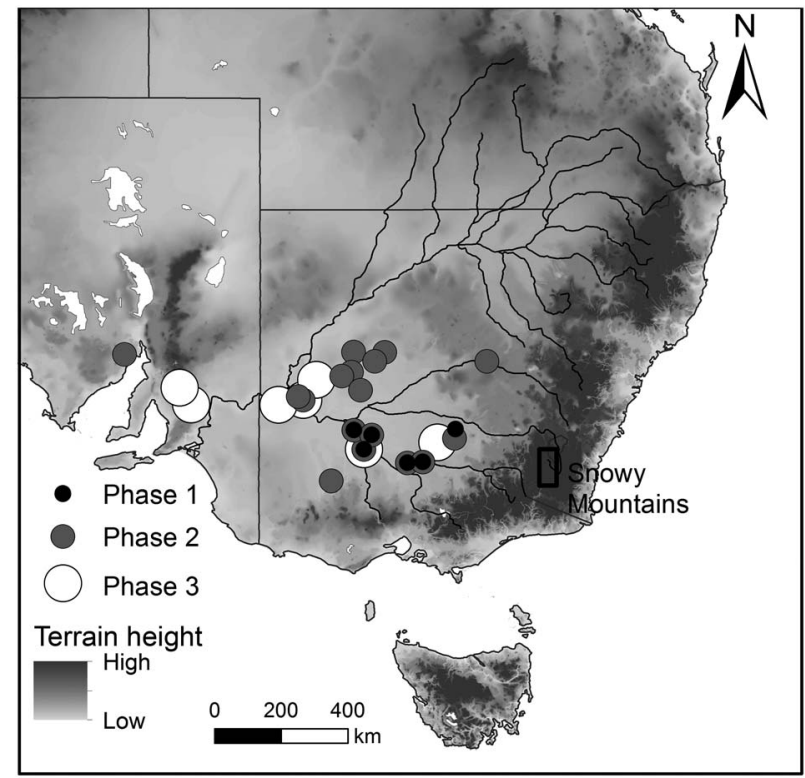

Figure 5. The source of dust deposited in the Snowy mire core during the different deposition phases, where phase 1 is 1700-1879, phase 2 1880-1989, and phase 3 1990-2006.

deposition after 1989 where rates $\left(25.4 \mathrm{~g} \mathrm{~m}^{-2} \mathrm{yr}^{-1}\right)$ were comparable to those during the pre-European period.

[22] There are a number of specific events in the dust deposition record that accord with historic events, including the pulses coinciding with cool phases of the LIA (A, Figure 4). The 1880s spike (B, Figure 4) signals the onset of agriculturally induced wind erosion from the MDB. The largest pulses in the record (C and D, Figure 4) coincided with the Federation (1895-1903) and 1911-1915 droughts. Other significant pulses include: the Dust Bowl era of the late 1930s and early 1940s (E in Figure 4) and drought periods in the early 1970s (F in Figure 4) and 1980s (G in Figure 4).

[23] A trend of decreasing dust deposition was apparent in the 1880-2006 portion of the core (Table $1 ; r^{2}=0.38$, $p$ value $=<0.00006)$ associated with an average decline in deposition rates of $0.46 \mathrm{~g} \mathrm{~m}^{-2} \mathrm{yr}^{-1}$. Apart from this, there were only very weak trends evident in other subsets of the record (see the slopes and $r^{2}$ values in Table 1).

\subsection{Dust Provenance}

[24] The chemistry of the dust deposited in the core implied that it was overwhelmingly sourced from the central-southern MDB. During phase 1 dust was sourced exclusively from the Murray and Murrumbidgee Rivers and their floodplains (Figure 5). In phase 2 dust was sourced more widely from the MDB, including the Murray and Murrumbidgee Rivers, the Lachlan River, the Murray-Darling confluence region and plains between the Darling and Murray Rivers, and the Wimmera region in western central Victoria. Some dust also displayed chemical affinity with sediments collected from Eyre Peninsula. During phase 3 the sources of dust were again more spatially restricted in comparison to phase 2 , albeit only slightly. They included the Murray and Murrumbidgee Rivers, the region around the Murray-Darling confluence, and cropping regions around the Mount Lofty Ranges (SA). The dominance of the MDB as the source of dust in the core is unsurprising given it is the closest dust source to the study site and a major contemporary dust source [McTainsh et al., 1998, 2011; Webb et al., 2006].

\subsection{Metal Deposition}

[25] The concentrations of a number of heavy metals in the core were found to show appreciable increases after European settlement. This included $\mathrm{Pb}, \mathrm{Zn}, \mathrm{Cu}, \mathrm{Mo}, \mathrm{Ag}, \mathrm{As}, \mathrm{Cd}, \mathrm{Sb}, \mathrm{Zn}$, In, $\mathrm{Cr}$, and Ni and was reported in detail in Marx et al. [2010]. In this section we report changes in the enrichment factors of

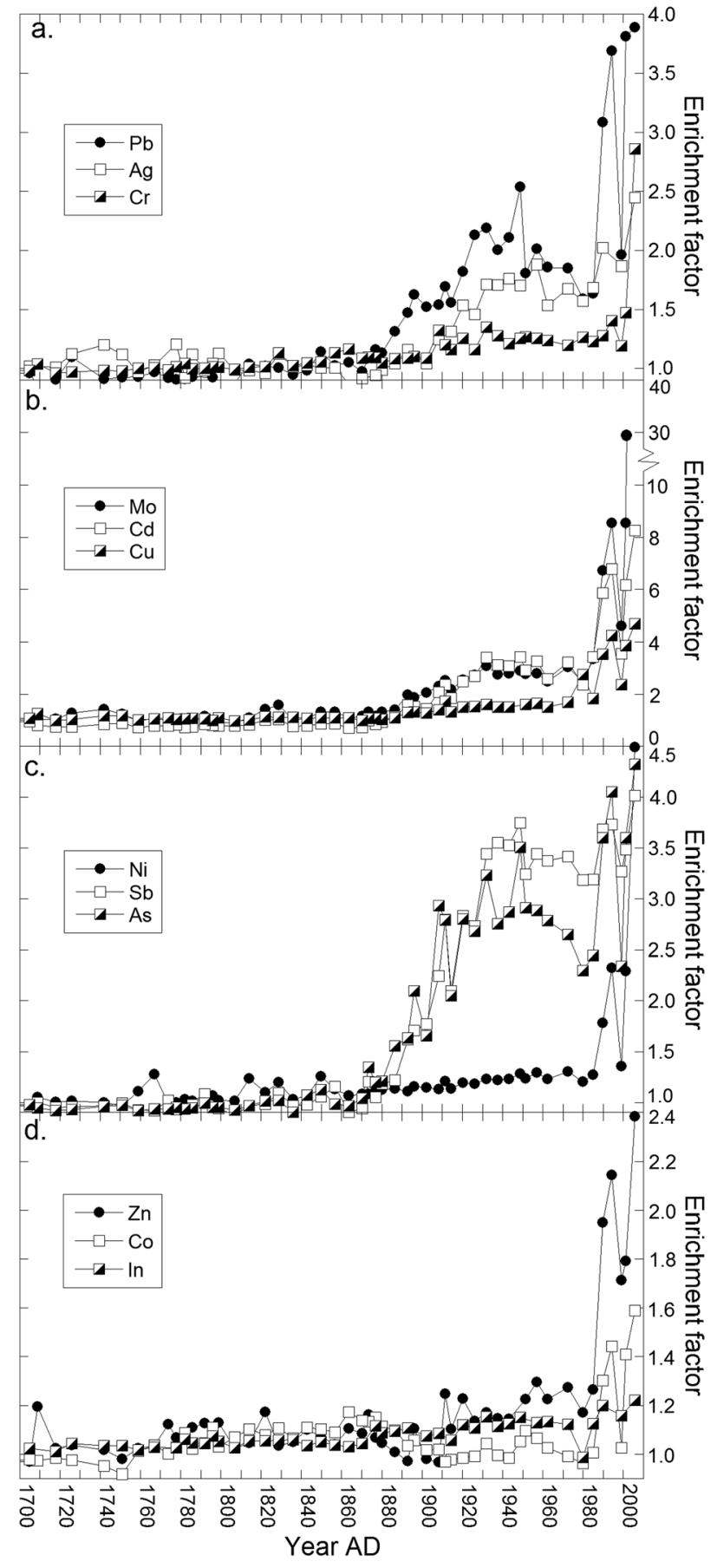

Figure 6. Enrichment factors for various metals in the Snowy mire core 1700 to 2006. 


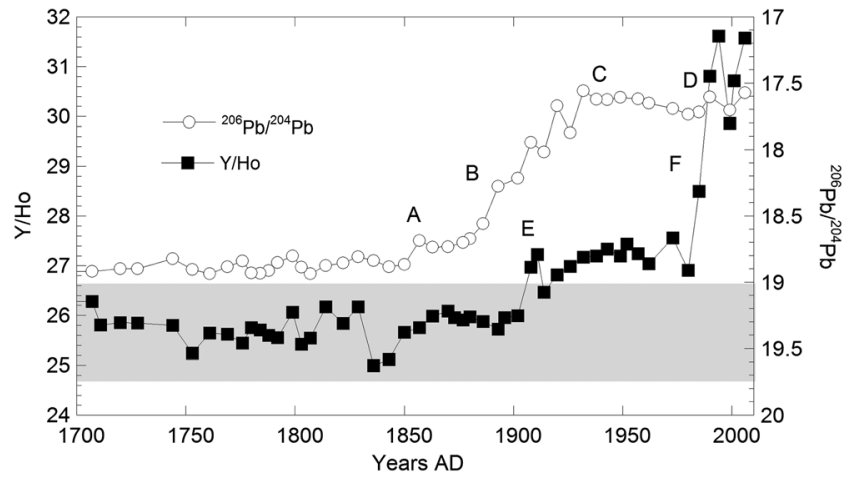

Figure 7. Lead isotope $\left({ }^{206} \mathrm{~Pb} /{ }^{204} \mathrm{~Pb}\right)$ and $\mathrm{Y} / \mathrm{Ho}$ ratios plotted against time through the Snowy mire core [after Marx et al., 2010]. Letters on the plot refer to $\mathrm{A}=$ early $\mathrm{Pb}$ mining in Australia; $\mathrm{B}=$ the start of $\mathrm{Pb}$ mining at Broken Hill; $\mathrm{C}=$ the introduction of leaded fuel to Australia; $\mathrm{D}=$ its subsequent phasing out; $\mathrm{E}=$ the start of phosphate fertilizer use; and $\mathrm{F}=$ increasing phosphate-derived fertilizer pollution in the core. Note that $\mathrm{Pb}$ isotope data are plotted with a reverse $y$ axis.

these metals through time. Enrichment factors were calculated from equation (4):

$$
E f=\left(C m / C c_{\text {ex }}\right) /\left(C m / C c_{\text {natavg }}\right)
$$

where $E f$ is the enrichment factor, $C m / C c_{\text {ex }}$ the ratio of a metal whose concentration is suspected of being perturbed $(\mathrm{Cm})$ in the post-1850 portion of the core against a conservative element $(C c)$, and $C m / C c_{\text {natavg }}$ is the average ratio of $\mathrm{Cm}$ to $C c$ in the prepollution (pre-1850) section of the core [Arimoto et al., 1989; Shotyk, 2002]. To limit the possibility that the behavior of the conservative element affects the metal $E F$, the average $E F$ values calculated using four conservative elements ( $\mathrm{Ta}, \mathrm{Ga}, \mathrm{Sc}$, and $\mathrm{Ti}$ ) are presented. Tantalum (Ta), Sc, and Ti are known to behave conservatively and have previously been used to calculate EF [Marx et al., 2010; Shotyk, 2002; Shotyk et al., 2001], while a Ga has behavior analogous to $\mathrm{Al}$ (which is also commonly used to calculate EF) [e.g., Arimoto et al., 1995].

[26] $E F$ for various metals through the core are shown in Figure 6. $E F$ values of $\sim 1$ or less occurred before 1880 and indicated that metal deposition in the core is comparable to background natural deposition rates, implying no additional (anthropogenic) metal loading is present in the environment. With the exception of In and Co which shows relatively minor enrichment, all the plotted metals demonstrate enrichment within the core after 1980 by approximately 2-5 times. Maximum $E F$ occurred at the top of the core, implying that accumulation of metals in the Australian environment has increased toward the present. For Mo and $\mathrm{Cd}$ recent accumulation was $30 \pm 5.4$ and $8 \pm 1.5$ times natural rates in the uppermost part of the core, respectively; $\mathrm{Sb}, \mathrm{Ni}, \mathrm{As}$, and $\mathrm{Pb}$ were $>4 \pm 0.8$ times; and $\mathrm{Cr}, \mathrm{Ag}$, and $\mathrm{Zn}$ were $>2 \pm 0.5$ times natural rates (pre-1850 samples).

\section{Discussion}

[27] The core dust record from 1700 B.P. until the present can be divided into three broad phases of deposition. These are (1) a pre-Anthropogenic phase (prehistory to approximately late 1870s); (2) the initial Anthropocene, associated with agricultural and mining expansion (1880s to late 1980s); and (3) the later Anthropocene phase (late 1980s until the present) associated with a cultural and technological revolution in Australia, resulting in increased mineral extraction and agricultural production, but with significantly improved land management. Collectively, these latter two phases represent the Anthropocene in Australia. Dust deposition and metal enrichment during these phases are discussed in the following sections.

\subsection{Pre-Anthropocene Dust and Metal Deposition}

[28] From 1700 to 1879 substantially lower dust deposition occurred by comparison to 1880-1990 (Figure 4). Dust deposition rates during this period can be considered natural background conditions as similar deposition rates occurred for the previous 2000 years B.P. (as shown in Marx et al. [2011]). In southeastern Australia variability in dust deposition during the middle to late Holocene was attributed to broad scale variability in the strength and position of the midlatitude westerly winds. However, at no point in the 6500 years B.P. presented in Marx et al. [2011] did dust deposition exceed the1880-1990 rates.

[29] Within the pre-Anthropocene period two dust pulses were evident, 1740-1780 and 1812-1845, corresponding with cold phases in the LIA ( 1550-1850), during which deposition rates were 1.5 to 2 times the average $1700-1870$ background. The LIA was a period of cooler global high-latitude temperatures, glacial advances and possibly intensified atmospheric circulation, which may have affected precipitation in Australia [Hendy et al., 2002]. For example, proxy river discharge records for southeastern Australia (including the MDB) indicate dry conditions during these periods [Gergis et al., 2012; McGowan et al., 2009; Verdon and Franks, 2006]. Similarly, palaeorainfall records from northern Australia indicate extended dry conditions from 1760 s to 1850 s with particularly dry periods in the 1780s and 1840s [Lough, 2011]. These correspond with dust deposition peaks in the studied mire.

[30] Metal enrichment in sedimentary deposits has long been recognized as a marker of industrial activity [Chow and Patterson, 1961; Hong et al., 1996], while the concentrations of metals in atmospherically fed environments, such as lakes, mires, and ice, are taken to broadly reflect the state of metal perturbation in the atmosphere through time [Brännvall et al., 1999; Shotyk, 2002; Vallelonga et al., 2010]. Although metal mining commenced in Australia as early as the mid-1840s, production rates were low [Mudd, 2007]. Similarly, coal production/combustion was also low, despite being mined from European settlement (1770s) [Weng et al., 2012]. There is little evidence of this early mineral resource use recorded in the studied core, with $E F$ close to, or below unity $(E F=1)$ (Figure 6) throughout the preAnthropocene period. The first sign of metal perturbation is, however, evident in the $\mathrm{Pb}$ isotope data, as a minor compositional change at 1850 [Marx et al., 2010] (A in Figure 7), associated with the earliest significant $\mathrm{Pb}$ mining operation in South Australia [Mudd, 2007]. This demonstrates that perturbation of metals in Australia dates from post-European settlement. By comparison, studies from the Northern Hemisphere typically show longer pre-Anthropocene pollution histories, reflecting a much longer history of metal use, e.g., Bronze Age smelting is recorded in European and 


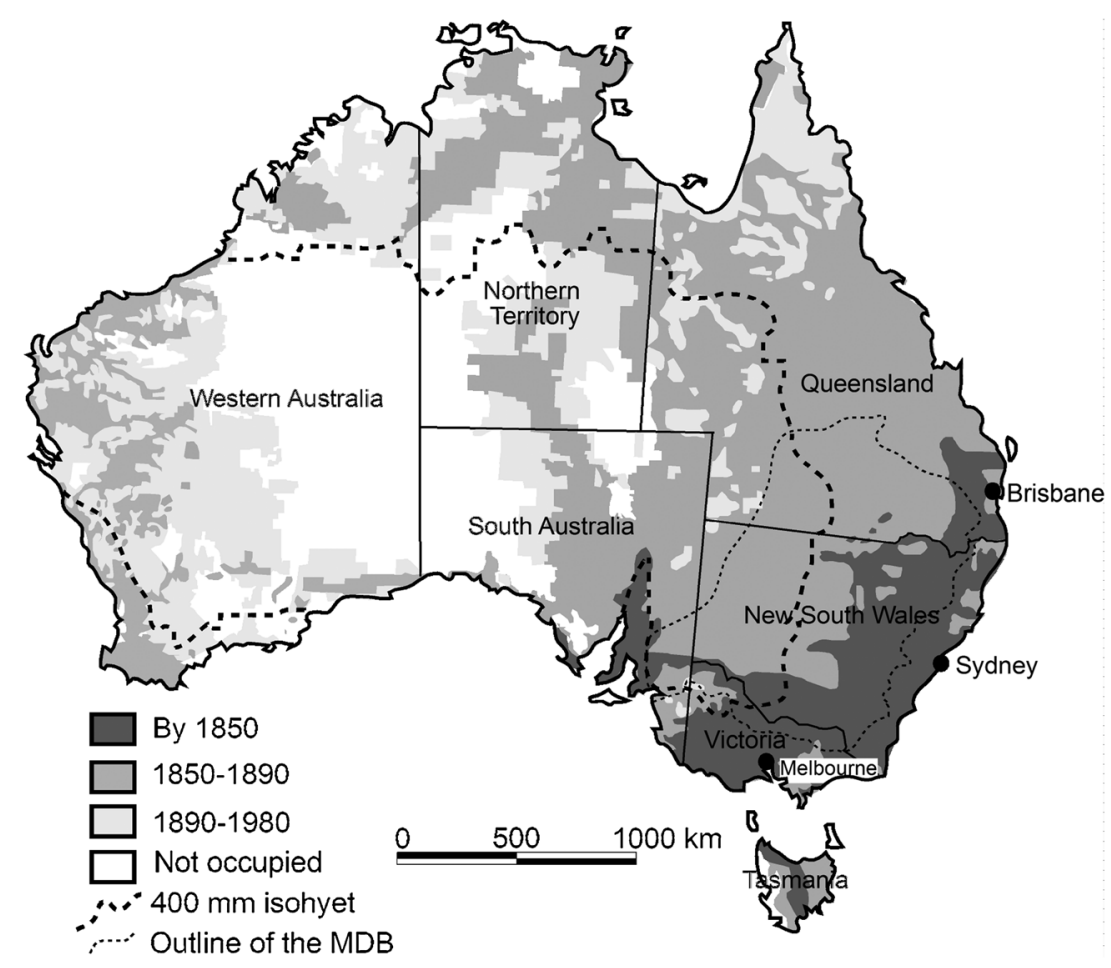

Figure 8. Pastoral development of Australia through time (modified after Henzell [2007]).

Asian lakes and mires dating from 4000 and 5000 years B.P., respectively [Le Roux et al., 2004; Lee et al., 2008].

\subsection{The Initial Athropocene Phase: Exploration and Intensification}

[31] European settlers commenced farming in the MDB from the 1820 s, extensively developing the entire basin for pastoralism by the 1880s (Figure 8) [Pearson and Lennon, 2010]. A significant increase in dust deposition was not recorded in the core until the 1880s (B in Figure 4) but was followed by a century of greatly increased deposition rates. Concomitantly, enrichment factors for metals (Figure 6) began increasing from the 1890 s in the core, reaching $\sim 2$ times background rates by 1920 for many metals. We suggest that enhanced dust deposition and metal enrichment marks the beginning of the Anthropocene in Australia.

[32] There are a number of factors that may have contributed to the century of accentuated wind erosion after 1880 . The predominant cause, however, appears to be the development of widespread agriculture from the 1880s, including the expansion of pastoralism into semiarid regions of NSW (facilitated by development of railways), and a shift from pastoralism to intensive cropping on the riverine plains of the MDB [Henzell, 2007; O'Gorman, 2013]. The extent of landscape modification for agriculture (both pastoralism and cropping) in Australia has been considerable (Figure 8). Fifteen percent of the continent has been cleared or severely modified, with much of this concentrated in southeast Australia, while extensive grazing covers an estimated $43 \%$ of the continent [McAlpine et al., 2009]. Today $67 \%$ of the MDB has been developed for pasture, $10 \%$ for cropping, and $1.8 \%$ is irrigated, with approximately $20 \%$ of basin covered by native vegetation [Leblanc et al., 2012]. The dust record shows the influence of this agricultural expansion from the
$1880 \mathrm{~s}$, when dust deposition increased by an average of 2.5 , and up to 10, times the pre-Anthropocene rates (Figure 4).

[33] Rapid westward expansion of agriculture (initially cattle followed by sheep) across the MDB took place after 1830 (Figure 8). This was driven by a wool boom from 1875 to 1890 (in which Australia became the major global wool producer) and by the discovery of ground water and the construction of dams (which facilitated agriculture in semiarid lands) [Pearson and Lennon, 2010]. The expansion of grazing in the MDB is illustrated by the rapid increase in stock numbers from the middle of the nineteenth century (Figure 9c). After the establishment of railways from the 1880s, cropping in the MDB expanded rapidly, occupying land previously used for grazing [Henzell, 2007; O'Gorman, 2013] (Figure 9d); associated with this was increased tillage. Numerous studies have demonstrated that conventional tillage (as initially used in the MDB [Henzell, 2007]) increases wind erosion rates in semiarid environments [Fister and Ries, 2009; Lopez et al., 1998; Nordstrom and Hotta, 2004; Shen et al., 2005]. For example, plowing has been argued to be a major contributing factor to the U.S. Dust Bowl in the 1930s [Lal, 2007]. These studies support the view that pastoral expansion and cropping have driven the increase in dust emissions in eastern Australia from the 1880 s indicated by our results. This is also supported by expansion in the spatial area supplying dust to the mire during the initial Athropocene phase (Figure 5), which is consistent with patterns of agricultural development shown in Figure 8. In particular, pastoral expansion into the semiarid Western Division of NSW (a region documented to have experienced severe wind erosion after 1880 [Condon, 2002]) and cropping in the Riverina region (around the confluence of the Murray and Darling Rivers) which was facilitated by large-scale irrigation [Henzell, 2007]. Associated with this was the removal of native vegetation resulting in the exposure 


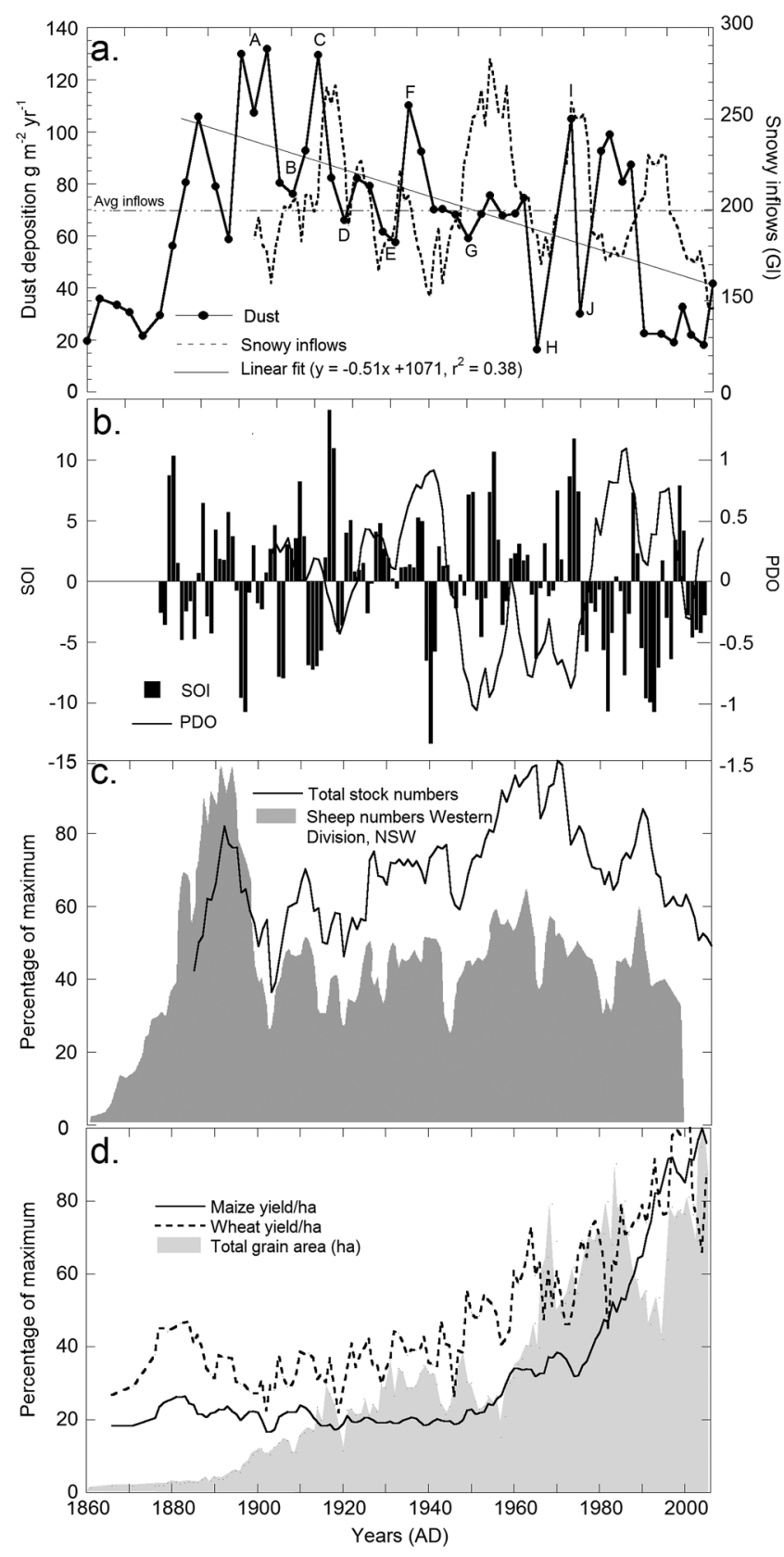

Figure 9. (a) Dust deposition in the Snowy peat core (1860-2000) plotted alongside inflows into the Snowy Hydro Electric Scheme (data from Snowy Hydro Ltd.). A linear trend line is shown fitted to the 1880-2006 dust deposition data. The letters on the figures refer to events described in the main text. (b) The Southern Oscillation Index (1860-2006) and Pacific Decadal Oscillation (PDO) (1900-2006) (data obtained from http://jisao.washington.edu/ao), smoothed with a 2 year and 5 year running mean, respectively. (c) Total New South Wales (NSW) stock numbers (cattle and sheep) (data from Australian Bureau of Statistics: http://www.abs.gov.au) and sheep numbers in the Western Division of NSW (data from Abel et al. [2006]) from 1860 to 2006. (d) Wheat and maize yields and total area of wheat for NSW from 1860 to 2006 (data from Australian Bureau of Statistics: http://www. abs.gov.au). of previously stable soils to the wind. Erodibility of surface soils is believed to have been exacerbated by the introduction of hard-hoofed animals which damage fragile soils, by breaking up protective natural soil surface crusts [Belnap and Gillette, 1998; Fister and Ries, 2009; Webb and Strong, 2011].

[34] There are additional indirect factors which are likely to have contributed to the wind erosion episode. Rabbits were introduced to mainland Australia in 1859, with numbers reaching plague proportions by the $1880 \mathrm{~s}$, damaging soils and stripping cover vegetation [Condon, 2002; McKeon et al., 2004]. Alteration of the hydrological regime (by vegetation clearance) across large parts of inland Australia has likely similarly increased erodibility. Rising groundwater (due to lower transpiration and reduced interception loss following vegetation clearance) mobilized salts stored in the regolith and caused soil salinity [Leblanc et al., 2012]. This resulted in further vegetation destruction exacerbating erosion in broad areas of eastern Australia [Chassemi et al., 1995; Peck, 1993]. Additionally, widespread vegetation clearance for agricultural has been shown to have resulted in decreased rainfall (4-12\%), increased temperatures $\left(0.4-2^{\circ} \mathrm{C}\right)$, and more severe drought [McAlpine et al., 2007], all further predisposing soils to entrainment by the wind [Pye, 1987].

[35] The role of agriculture in driving enhanced broadscale wind erosion has similarly been demonstrated in other semiarid agricultural landscapes. Dust deposition in two alpine lakes downwind of the dry lands of the western U.S. increased by 5 times in response to regional agricultural development from the early 1800s [Neff et al., 2008]. Similarly, a fivefold increase in wind erosion in the Sahel region of North Africa since the early eighteenth century (recorded as dust deposition in a marine core) was attributed to the introduction of commercial cropping of maize $(\sim 1700 \mathrm{~s})$, millet $(\sim 1750 \mathrm{~s})$, and ground nut (1840s) and associated agricultural expansion [Mulitza et al., 2010]. In the Southern Hemisphere, a doubling of dust deposition rates after the midtwentieth century were recorded on the Antarctic Peninsula [McConnell et al., 2007]. This was attributed to a combination of land use change (overgrazing and deforestation) and climate change (higher temperatures and evaporation and lower precipitation) in the dust source areas of southern Argentina. The results of these studies are analogous to those presented here. Taken together, they show the dramatic effect of agricultural development on the soil resource in areas susceptible to wind erosion, i.e., a twofold to fivefold increase in soil loss via the wind. While there are currently few studies that clearly show the effects of agriculture on broad-scale wind erosion, approximately $1 / 3$ of Earth's landmass is arid or semiarid and much of this, like in Australia, has been developed for agriculture. Consequently, it would seem likely that the effect of agriculture on land degradation at a global scale has been more significant than has been widely acknowledged.

[36] Enrichment of $\mathrm{Pb}, \mathrm{Zn}, \mathrm{Mo}, \mathrm{Ag}, \mathrm{As}, \mathrm{Cd}, \mathrm{Sb}, \mathrm{Zn}$, and $\mathrm{Cr}$ (Figure 6) began in the mire during the initial Anthropocene phase. In this study, as for others [e.g., Brännvall et al., 1999; Le Roux et al., 2004; McConnell and Edwards, 2008], the timing of changes in metal $E F$ can be linked to historical changes in industrial activity [Marx et al., 2010]. These metals are likely to be deposited both alongside mineral dust (which can scavenge metal pollutants from the atmosphere), as well as independently by primarily wet but also potentially 
dry deposition [Fujiwara et al., 2006; Han et al., 2004; Marx et al., 2008]. While it is not often possible to identify point sources of these metals, which can be produced by a range of industrial activities, including primarily metal production and mining but also fossil fuel combustion, cement production, and waste disposal [Pacyna and Pacyna, 2001], increased $E F$ for $\mathrm{Pb}, \mathrm{As}, \mathrm{Sb}, \mathrm{Cu}, \mathrm{Cd}$, and Mo (which began $\sim 1890$ in the mire) coincides with the onset of mining at Broken Hill, a globally important $\mathrm{Pb}, \mathrm{Ag}$, and $\mathrm{Zn}$ ore body $\sim 800 \mathrm{~km}$ upwind of the study site (Figure 1). The release of $\mathrm{Pb}$ particulate from Broken Hill to the atmosphere is also independently recorded via $\mathrm{Pb}$ isotopes (Figure 7), which record the presence of less radiogenic $\mathrm{Pb}$ (i.e., lower ${ }^{206} \mathrm{~Pb} /{ }^{204} \mathrm{~Pb}$ ratios) [Marx et al., 2010]. Intriguingly, Ag showed no obvious enrichment at this time, presumably because the quantities recovered/released were not sufficient to result in significant perturbation. Zinc enrichment occurred after 1900, when Zn mining at Broken Hill commenced [Marx et al., 2010].

[37] Although the specific EF for these metals vary, most display the same general pattern during the initial Anthropocene (with the exception of $\mathrm{Zn}$ ), that is, $E F$ factors reach a plateau between about 1925 and 1950 before decreasing slightly until $\sim 1980$. The steady rise in $E F$ until $\sim 1950$ indicates increased perturbation of these metals, reflecting the increasing scale of Australian mining operations. For example, from 1890 to $1970, \mathrm{~Pb}$ production increased from approximately $60,000 \mathrm{t}$ to $>400,000 \mathrm{t}$ and $\mathrm{Cu}$ from $10,000 \mathrm{t}$ to $>200,000 \mathrm{t}$, while $\mathrm{Zn}$ increased from $<20,000 \mathrm{t}$ in 1900 to $>400,000 \mathrm{t}$ by 1970 [Mudd, 2007]. $E F$ in the core rose from $\sim 1$ to $>3 \pm 0.3$ for $\mathrm{Cd}$, Mo, As, and $\mathrm{Sb},>2 \pm 0.2$ for $\mathrm{Pb}$ and $\mathrm{Zn}$, and $>1.2 \pm 0.1$ for $\mathrm{Ag}, \mathrm{Cr}$, and $\mathrm{Cu}$. Cobalt and $\mathrm{Ni}$ exhibited no significant enrichment, whereas $E F$ for In increased above background but were $<1$ (Figure 6). The scale of metal perturbation during the initial Anthropocene phase in Australia is, however, considerably lower than in Europe, with $\mathrm{Pb} E F$ in alpine Swiss mires $\sim 100$ by the early 1800 s, reflecting the much greater extent European industrial activity [Shotyk, 2002]. Interestingly, the reduction in $E F$ factors in our core between $\sim 1950$ and 1980 may reflect a shift in the locus of metal production in Australia from southeastern Australia before 1950, to northern and western Australia between 1950 and1980, with mining and smelting regaining importance in southeastern Australian after 1980 [Mudd, 2007].

\subsection{Climate Variability and Enhanced Wind Erosion}

[38] A number of individual wind erosion pulses are evident in the post-1880s section of the core. These include the Federation Drought (1897-1902), the largest dust deposition pulse in the core, the 1913-1915 drought, and the Dust Bowl Era (late 1930s to early 1940s) (C, D, and E in Figure 4), recognized as major land degradation events in Australia and associated with severe drought [McKeon et al., 2004]. Documented oral reports during the Federation Drought offer an impression of the severity of wind erosion, e.g., "At Menindee [western New South Wales] the church picket fence, $4 \mathrm{ft}$. 6 ins. $[1.35 \mathrm{~m}]$ high is all but covered [in windblown sediment]" and "there was not a single sheep proof fence left on the place. Every fence, at some point or other, was so far buried that stock could go from paddock to paddock" (Parliamentarian E.D., Millian cited in Condon [2002]). The Dust Bowl Era was also marked by severe dust storms [Condon, 2002; McKeon et al., 2004; McTainsh and
Leys, 1993] and apparent reactivation of dune fields in the lower MDB during the 1930s [Lomax et al., 2011; Twidale et al., 2007]. The beginning of this episode, in the late 1930 s, is marked by significant dust deposition in the mire; however, the later period in the early 1940s is not recorded in the sedimentary record. The later part of this dust pulse may have been less severe, although significant wind erosion was documented through the early 1940s. Alternatively, it is possible that the mire dried out during this event and did not act effectively as a dust trap. This later hypothesis is supported by records of inflows in the headwater catchments of the Murray River which shows the lowest discharge on record occurred in the late 1930s (Figure 9a).

[39] Dust deposition pulses in the core are typically associated with severe drought. These occur coincident with extended periods of low inflows to the headwater catchment of the Murray River (Figure 9a). They are more frequent during cool (negative) phases of the Pacific Decadal Oscillation (PDO) and El Niño-Sothern Oscillation (ENSO) events (Figures $9 \mathrm{~b}$ and 10). All eight dust pulses recorded after 1880 were associated with El Niño events (i.e., 1882-1890, 1894-1904, 1911-1915, 1939-40, 1972-73, and 1979-87, as well as minor pulses 1997-2000 and 2006-2007) (Figures 9a and 9b). However, due to the spatial and temporal variability in the effect of the ENSO on precipitation in Australia [Cai et al., 2010], and therefore wind erosion [Webb et al., 2006], it is not possible to model these effects using time series analysis. Warm phases of the PDO, which follow a quasimultidecadal pattern (i.e., prevailing between 1902-1944 and 1978-2008), tended to be associated with a drier climate regime and more frequent El Niño events (e.g., the ratio of El Niño to La Niña events is 2.75 during warm PDO phases and 0.75 during cool phases). Of the six dust pulses recorded in the core since 1905 (the start of the PDO record) five were associated with warm phase PDO conditions. The relationship between warm PDO events and elevated dust emissions in Australia has similarly been demonstrated by wind erosion modeling [Webb et al., 2009], analysis of meteorological observations [Lamb et al., 2009], and analysis of land degradation episodes [McKeon et al., 2004]. Unsurprisingly, years of low dust deposition in the mire correlated with relatively wet conditions in dust source areas. For example, wet conditions in 1906-1908, 1919, 1928-1931, 1949, 1964-1965, and 1974-1975 (B, D, E, G, H, and J on Figures 9a and 11) resulted in relatively lower dust deposition.

[40] Some dust pulse sequences show more varied patterns in relation to the ENSO, reflecting the complex spatial nature of drought, wind erosion, and the impact of teleconnections on the Australian climate [Leblanc et al., 2009; Verdon-Kidd and Kiem, 2009; Webb et al., 2009]. For example, despite a strong El Niño event in 1965-1966, causing significant land degradation in central Queensland [McKeon et al., 2004], dust deposition in the mire remained low (Figures 9a and 9b). This is likely a function of wet antecedent conditions in the MDB (i.e., 1947-1963, Figure 9a) combined with average rainfall in dust source areas in the southern MDB during 1965 (Figure 10d). A dust pulse was, however, recorded in the core in the early 1970s (I in Figure 9a), following more moderate El Niño events in 1969-1970 and 1972-1973, both of which had a greater effect on reducing rainfall within dust source areas (Figure 10e). Other El Niño events, e.g., 1905-1906, 

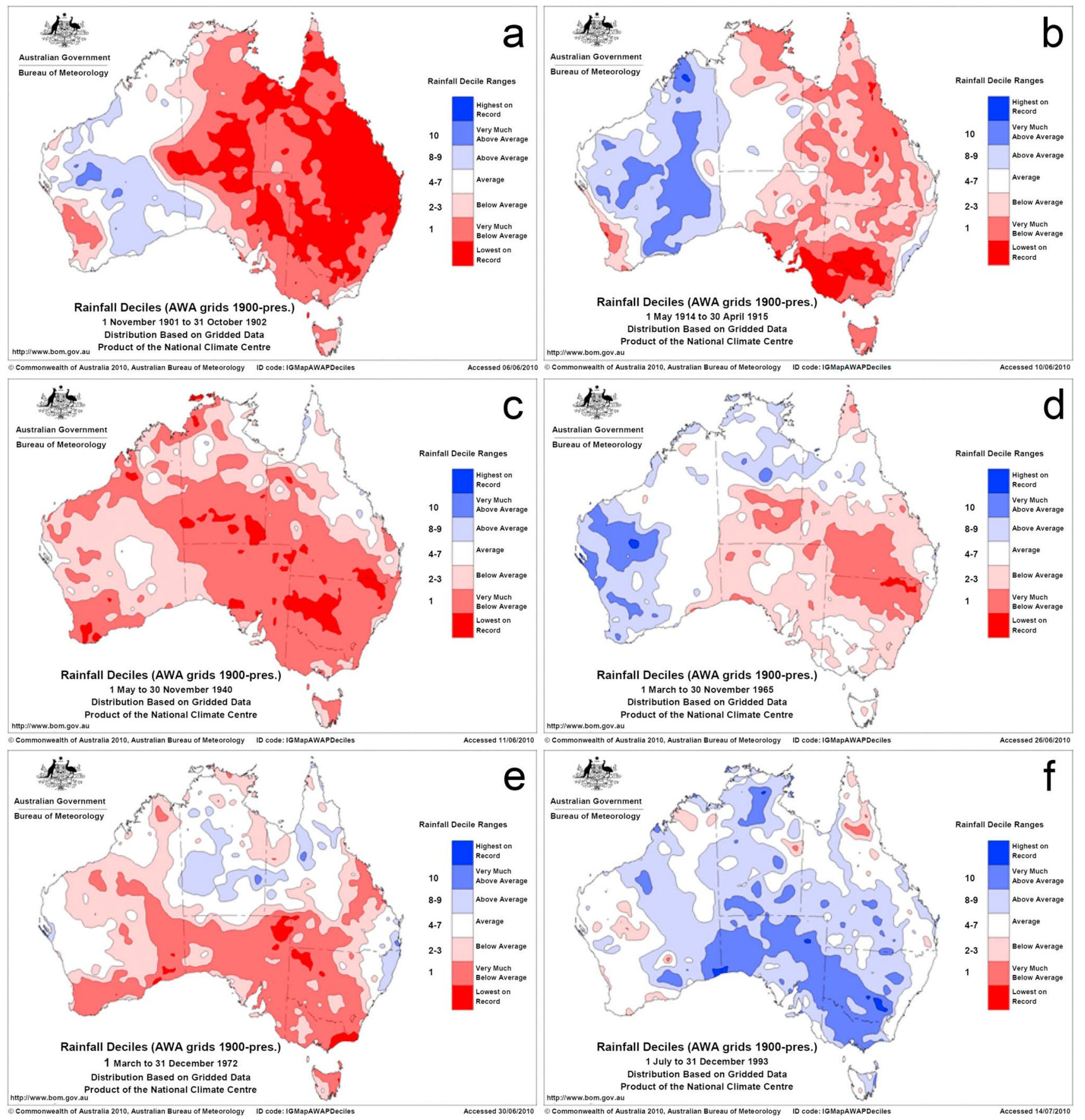

Figure 10. Rainfall deciles in Australia during El Niño conditions for selected periods (images from Australian Bureau of Meteorology: www.bom.gov.au).

1919-1920, 1925-1926, 1951-1952, 1957-1958, 1963-1964 1976-1977, and 1990-1994 and 2002-2003 similarly did not result in dust pulses (Figures $9 \mathrm{a}$ and $9 \mathrm{~b}$ ). With the exception of the 2002-2003 El Niño event, these had little effect on the hydroclimatology of the MDB (shown by relatively high inflows into the Murray River during these years) (Figure 9a). For example, during the 1990-1994 event, above average rainfall occurred within dust source areas (Figure 10f) and more generally in the MDB as shown by increased inflows into the Murray River (Figure 9a).

[41] Despite variability in the impact of the ENSO in eastern Australia, the overall impression is that dust pulses recorded in the mire were typically associated with protracted drought events (e.g., persistent El Niño conditions) and warm phases of the PDO, although due to spatial variability in the effects of the ENSO in Australia, the response in dust emissions is similarly variable.

\subsection{Net Soil Loss as a Result of Agricultural Activity}

[42] There is an overall decreasing trend in dust deposition between 1880 and 2006 (Figure 9a), while individual dust pulses show diminished magnitudes relative to drought severity, as indicated by inflows into the Murray River (Figures 9a and $9 \mathrm{~b}$ ). This may imply a net reduction in erodible soil from 

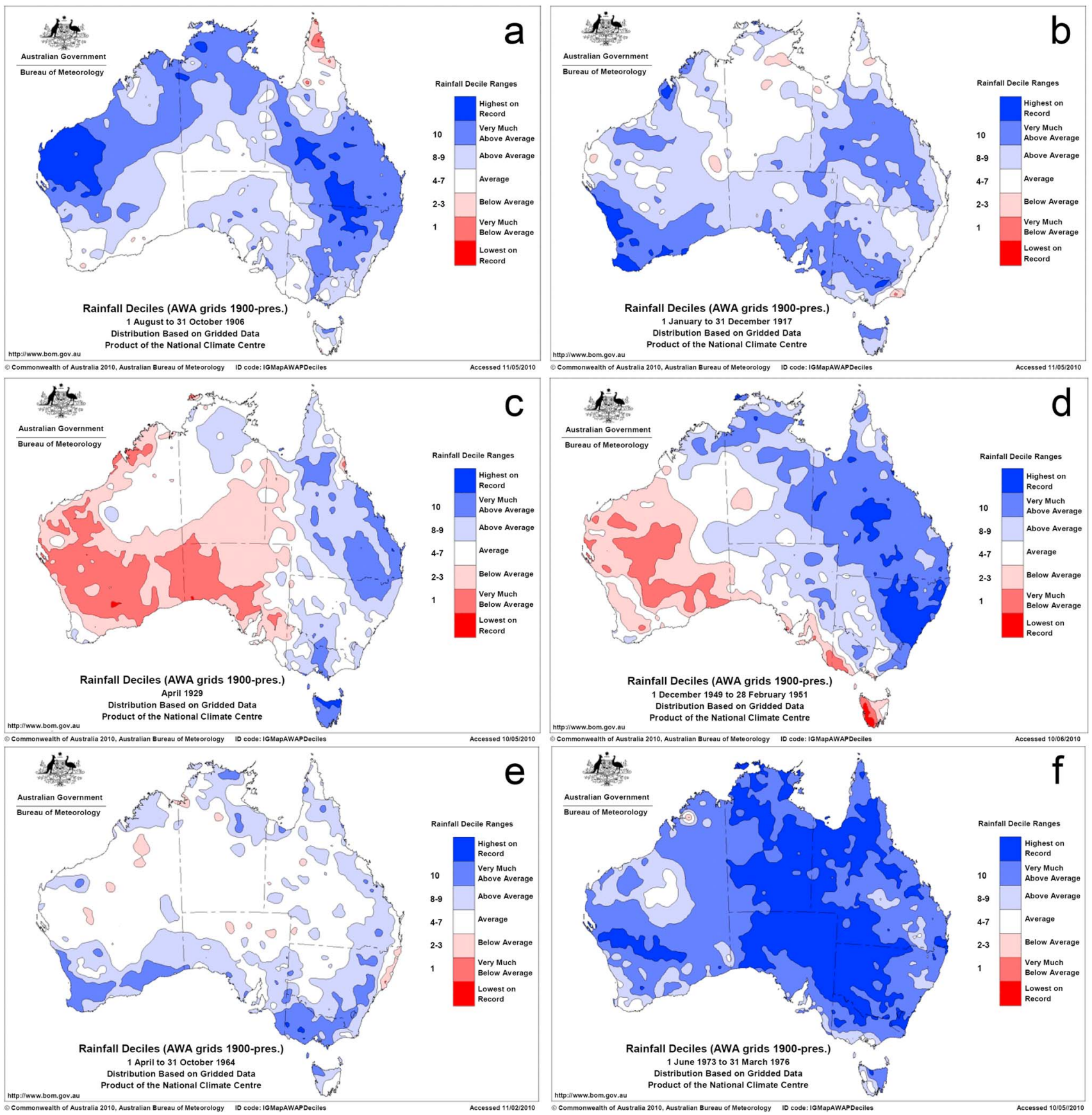

Figure 11. Rainfall deciles in Australia during La Niña conditions for selected periods (images from Australian Bureau of Meteorology: www.bom.gov.au).

the MDB following agricultural development, where erosion rates have exceeded rates of soil formation and replenishment over the last 120 years. An impression of the perceived changes which occurred to soil structure following agricultural development in Australia is provided by documented oral reports. These describe the condition of soils in the MDB after 1900 as " .... transformed .... from .... (their) original soft spongy absorbent nature to a hard clayey smooth surface..." (J. Cotton cited in Condon [2002]) and " .... What used to be rich fine flats, covered with the best cotton-bush along with succulent herbage of all kinds, were now nothing but an enormous claypan [scald]", while "... water holes soon became silted up as wind-blown sand dropped in the creeks " (B. Hendy cited in Condon [2002]). This latter report may describe the formation of erosion "scalds," treeless hard pans which occur on duplex soils through the MDB which are attributed not only to wind but also water erosion following drought and overgrazing early in the twentieth century [Beadle, 1948; Condon and Stannard, 1957; Ringrose-Voase et al., 1989].

[43] Soil loss by wind erosion was further enhanced by significant fluvial erosion on land cleared of vegetation. Average post-European alluvial sedimentation rates in the Barrier Range, on the western boarder of the MDB, were 
50 times those of the pre-European period, reaching 90 times the pre-European period between 1915 and 1941 [Wasson and Galloway, 1986]. Sedimentation rates in wetlands in the lower MDB increased by 20-30 times following European settlement [Gell et al., 2009]. Similarly, the widespread exposure of prehistoric aboriginal cooking pits that had remained buried for thousands of years also attests to the magnitude of soil loss following European settlement [Fanning, 1999].

[44] There are no known studies of soil formation rates in the MDB. However, rates of soil formation near Canberra, which is approximately $600 \mathrm{~km}$ from the main MDB dustproducing areas and experiences approximately double the rainfall, are between 1 and $7 \mathrm{~mm} \mathrm{ka}^{-1}$ (calculated using ${ }^{10} \mathrm{Be}$ ) [Fifield et al., 2010] and $10-24 \mathrm{~mm} \mathrm{ka}^{-1}$ calculated using uranium series [Suresh et al., 2013 ]. In the more humid coastal fringe of southeastern Australia, soil formation rates are $2-77 \mathrm{~mm} \mathrm{ka}^{-1}$ [Dosseto et al., 2008; Heimsath et al., 2000; Little and Ward, 1981; Walker and Coventry, 1976]. In all of these examples, rates of soil formation are expected to be higher than within the semiarid MDB. There are similarly few studies of wind erosion rates in Australia; however, estimates of current continental scale dust emissions [see Shao et al., 2011] averaged over Australia's main dustproducing regions [McTainsh et al., 1989] imply erosion rates of 13 and $53 \mathrm{~mm} \mathrm{ka}^{-1}$. Rates of wind erosion estimated during a single large dust storm are 4 orders of magnitude higher $\left(0.45 \mathrm{~mm} \mathrm{day}^{-1}\right)$ [McTainsh et al., 2005]. Despite uncertainties in rates of soil production and dust emissions, these numbers imply that in semiarid regions like the MDB, the balance between soil formation and net soil loss by wind erosion is likely to be highly sensitive to subtle changes. A change in landscape sensitivity to wind erosion driven by agricultural development could therefore easily tip the system into a state of net soil loss, as is implied by declining rates of dust deposition in our core. Additional evidence for this is provided by an independent record of Australian dust export, using atmospheric ${ }^{210} \mathrm{~Pb}$ that demonstrated the supply limited nature of Australia's dust emissions [Marx et al., $2005 \mathrm{~b}$ ]. That work implied that once fine surface sediments are removed, surface soils are rendered less susceptible to wind erosion through sediment starvation. Other factors that can contribute to net soil loss include reduced flood supply of sediment to alluvial plains due to altered hydrologic regimes, removal of vegetation resulting in reduced trapping of aeolian sediment, surface armouring, and surface compaction by stock [Fanning, 1999; Gell et al., 2009; Leblanc et al., 2012; Leys, 1999].

[45] Declining agricultural productivity has been linked elsewhere to net soil loss. For example, declining soil resource has been argued to be a contributing cause of slowing rates of global agricultural productivity [Brown, 1991; Lal, 2010; Pimentel et al., 1995], which in some cases can be directly linked to soil loss [Lal, 2010]. Similarly, historically, soil loss and resulting crop failure have been linked to the decline of previous civilizations, including, for example, the Roman Empire and the Phoenicians [Lal, 2010; Montgomery, 2007a]. Despite significant soil loss, eastern Australia remains a productive agricultural region. Yet there is evidence, however, that soil loss in Australia has reduced agricultural productivity. Wheat yields in the MDB have been shown to decline linearly as a function of soil loss [Rose and Dalal,
1998], while across NSW a $2 \%$ reduction in crop yield was attributed to wind erosion [Aveyard, 1988]. Similarly, crop yields showed a decline from the 1880s until the 1940s, after which new technology boosted yields (Figure 9d) [Donald, 1967; Henzell, 2007]. Stock numbers in NSW also declined after 1890, attributed in part to reduced soil fertility associated with severe erosion [Abel et al., 2006; Beadle, 1948; Condon, 2002; McKeon et al., 2004]. While total stock numbers again reached pre-1890s levels in NSW by the 1960s, sheep numbers in the western division have never recovered [Abel et al., 2006] (Figure 9c). While other factors, such as a switch from sheep to cattle and changing practices (adopting maximum stocking rates) have undoubtedly contributed to this, sheep stocking rates never regained the levels obtained prior to the Federation Drought, in part due to land degradation.

[46] Alongside the dust and metal pollution record, the core documents an increase in fertilizer pollution toward the present. This is shown by the topology of the Y/Ho ratio in the core (Figure 7), which began to increase after 1900 and more significantly from the 1980s. Enriched Y/Ho ratios serve as a proxy for phosphate fertilizer use, because the otherwise near constant $\mathrm{Y} / \mathrm{Ho}$ ratio in terrestrial sediments is enriched within the marine phosphate rock used to produce fertilizer [Marx et al., 2010]. Therefore, the increasing Y/ Ho ratio in the core broadly matches patterns of fertilizer use in Australia [Marx et al., 2010; McGarity and Storrier, 1986]. In the MDB, phosphate fertilizer has been applied since the early 1900s, primarily to cultivated land along the river systems and, to a much lesser extent, to pastoral lands. Indeed, increased fertilizer application, combined with development of herbicides, improved wheat varieties and other technological advances [Henzell, 2007], may have offset declines in crop productivity that would have otherwise occurred due to soil loss. We note, however, that wheat production in Australia, on a multiannual scale is correlated with rainfall variability [Rimmington and Nicholls, 1993].

\subsection{Improved Management (A Cultural and Technological Shift), Soil Starvation, or Changing Climate?}

[47] After 1990 dust deposition in the mire returned to preAnthropocene levels (i.e., 1990-2006 average deposition rates of $\sim 25 \mathrm{~g} \mathrm{~m}^{-2} \mathrm{yr}^{-1}$, Table 1) (Figure 4). We suggest this change marks the onset of the second phase of the Anthropocene in Australia. It is recorded in the core as a reduction in dust deposition, but an increase in metal enrichment (Figures 4 and 6). Decreased dust deposition after 1990 is attributed to three possible causes. First, it may be the result of the net soil loss causing sediment starvation. Second, it may be attributable to changing windiness. Third, it may reflect soil conservation measures in the MDB, which became more widespread from the late 1980s [McTainsh and Leys, 1993].

[48] A poleward expansion of the Hadley cell has occurred since the late 1970s [Seidel et al., 2008], resulting in a more southerly positioning of the Southern Hemisphere westerly storm track [Bengtsson et al., 2006; Thompson and Solomon, 2002] and reduced wind speeds across southern Australia [Frederiksen and Frederiksen, 2007], theoretically reducing dust emissions. Indeed, reduced dust storms in central Australia were observed during 1977-2006 by comparison to 1957-1973 and have been attributed to changes in the 
operation of the PDO and North Pacific Oscillation [Lamb et al., 2009]. Interestingly, an associated reduction in precipitation in southern Australia [Murphy and Timbal, 2008] between these periods, which would otherwise be presumed to result in increased dust emissions, may have been negated by reduced wind speeds. Reduced river discharge, as also observed during this period [McGowan et al., 2009], would likely have decreased alluvial deposition along the floodplains of the MDB, further reducing dust emissions. The core presented here shows a decline in dust deposition corresponding to changing climate and reduced dust observations, implying climatic factors have influenced dust emissions since 1990; however, the change in dustiness may also been attributed to changing land management.

[49] A shift in agricultural practices in Australia occurred after about 1990. This included changing technologies and increased environmental awareness in the agricultural sector, leading to more efficient production [Henzell, 2007]. In terms of wheat, for example, this included not only reduced tillage and increased crop rotation but also increased use of fertilizer [Henzell, 2007] (evident in the mire from increasing Y/Ho ratios, Figure 7). Consequently, crop yields, which began increasing in the $1950 \mathrm{~s}$, increased more significantly from the 1980s (Figure 9d). Soil conservation measures, including those aimed at reducing wind erosion became more widespread from the late 1980s [McTainsh and Leys, 1993]. These included the establishment of the National Soil Conservation Program (1983), the creation of local landcare groups (1989), and joint government institutions (state and federal) to manage the environment of the MDB (1985) [McDonald and Hundloe, 1993]. It is difficult to definitively gage the effectiveness of such programs; however, a study of soil erosion using ${ }^{137} \mathrm{Cs}$ soil redistribution suggested reduced erosion (combined water and wind) in 1990-2010 compared with 1950-1990 in the MDB. Similarly reduced dust activity in Australia between the 1940s and 2000s has been attributed in part to improved land management [McTainsh et al., 2011]. The respective role of these different factors cannot be clearly deconvoluted in this case; however, it is likely that changes in land management have contributed to declining dust deposition in the core over the last 20 years.

[50] Metal production in Australia increased rapidly from the late 1980s for a number of metals, including $\mathrm{Pb}, \mathrm{Ni}, \mathrm{Zn}$, and $\mathrm{Cu}$, which increased by approximately 1.8, 2.2, 2.5, and 4 times the initial Anthropocene phase, respectively [Mudd, 2007]. Similarly, production of coal increased in Australia in the 1960 s and more significantly from the 1980 s, with production in the mid-2000s $\sim 6$ times that of the mid-1970s [Weng et al., 2012]. Metal EF in the mire after 1990 increased by approximately 2 times the initial-Anthropocene phase and 4 times the pre-Anthropocene concentrations (Figure 6).

[51] Three features stand out as significant in Australian metal $E F$ by comparison to Northern Hemisphere studies. First, as previously stated, metal perturbation is limited to the last 160 years (within the Anthropocene epoch), second, $E F$ have increased rapidly, while third, $E F$ have increased toward the present. Metal enrichment in Europe took 600-1800 years to reach 4 times natural accumulation rates in remote from source locations [Le Roux et al., 2004; Shotyk et al., 1998], whereas in Australia it took 120 years. This reflects the fact that metal perturbation in Australia has been limited to the Anthropocene epoch in which the pace of environmental change has globally increased by 3-6 times (e.g., for global energy consumption and manufacturing) [Steffen et al., 2004], resulting in rapid metal enrichment in the atmosphere and surficial environments. In North America and Europe, heavy metal concentrations peaked in the 1970s, before declining due to reduced industrial activity and cleaner production [Brännvall et al., 1999; Le Roux et al., 2004; McConnell and Edwards, 2008; Osterberg et al., 2008; Pacyna and Pacyna, 2001]. In the studied mire, increasing metal $E F$ reflect increasing industrial activity in Australia [Mudd, 2007; Weng et al., 2012]. This has manifested as increasing soil metal concentrations and elevated $\mathrm{Pb}$ blood levels in some children living in industrial cities in Australia, despite the introduction of cleaner production methods [Taylor et al., 2010]. Overall, the $E F$ reported here support the finding that $\sim 50 \%$ of Earth's global $\mathrm{Ag}, \mathrm{Cr}, \mathrm{Cu}, \mathrm{Ni}, \mathrm{Pb}$, and $\mathrm{Zn}$ concentrations can be attributed to human activity [Rauch and Pacyna, 2009].

\section{Conclusion}

[52] This study highlights the significant environmental change that has occurred in Australia since European settlement. European settlement brought the Industrial Revolution to Australia and with it a period of pronounced global environmental change, known as the Anthropocene. The magnitude of these changes over natural conditions is quantifiable within the Australian landscape, because Australia's entire industrial and agricultural history occurs within this period. The studied mire contains a detailed record of these changes as its sediment composition reflects atmospheric particulate loads (both dust and pollution) through time. Three distinct phases were identified in the mire since 1700: (1) the pre-Anthropocene (before 1880) associated with natural dust and metal accumulation; (2) the initial Anthropocene (1880-1980) associated with agricultural and industrial expansion, causing increased dust and toxic metal accumulation; and (3) the later phase of the Anthropocene associated with technological expansion and increased environmental awareness, resulting in decreased dust deposition but increased metal accumulation.

[53] During the expansionary initial Anthropocene phase, the enrichment of metals began to be recorded in the mire from the 1890 s, with patterns in metal enrichment matching historical resource use patterns in Australia. The mire also recorded an increase in atmospheric dust loading, which began with the onset of widespread European style agriculture in Australia from the 1880 s. Dust emissions from eastern Australia increased by an average of 2.5 times (and peaked at up to 10 times) between 1880 and 1989 . This accords with previous catchment-scale studies, in addition to documented oral reports, which demonstrate significant wind erosion in inland Australia has accompanied development for agriculture. Dust deposition in the mire was particularly high following initial land development, with wind erosion exacerbated during prolonged drought episodes typically associated with El Niño events and warm phases of the PDO. Decreasing rates of dust deposition after European settlement and toward the present may result from a net-loss of erodible soil in source areas after 130 years of agriculture, as rates of wind erosion may have exceeded rates of soil replenishment.

[54] At the end of the 1980s, dust deposition in the core decreased to pre-Anthropocene levels. This was attributed 
to three factors: (1) improved land management, resulting from growing environmental concern, in combination with; (2) long-term soil loss; and (3) recent climate variability with reduced windiness over southern Australia during the last 35 years. Conversely, metal enrichment in the core increased after 1980, as the pace of resource extraction in Australia increased, reaching levels of 5 and up to 30 times background rates.

[55] Acknowledgments. This research was supported by an Australian Research Council (ARC) Linkage grant with Snowy Hydro Ltd. (LP0669104). Lead-210 dating was supported by an Australian Institute of Nuclear Science and Engineering (AINSE) Award (AINGRA08124). We thank Alexander Densmore, Bob Wasson, and four other reviewers whose constructive comments were greatly appreciated.

\section{References}

Abel, N., D. H. M. Cumming, and J. M. Anderries (2006), Collapse and reorganization in social-ecological systems: Questions, some ideas, and policy implications, Ecol. Soc., 11(1), 17.

Arimoto, R., R. A. Duce, and B. J. Ray (1989), Concentrations, sources and air-sea exchange of trace elements in the atmosphere over the Pacific Ocean, in Chemical Oceanography, SEARX: The Sea/Air Exchange Program, edited by R. A. Duce, J. P. Riley, and J. P. Chester, pp. 107-145, Academic Press, London, New York.

Arimoto, R., R. A. Duce, B. J. Ray, W. G. Ellis, J. D. Cullen, and J. T. Merrill (1995), Trace-elements in the atmosphere over the North Atlantic, J. Geophys. Res., 100(D1), 1199-1213.

Aveyard, J. M. (1988), Land degradation: Changing attitudes-why?, J. Soil Water Conserv., 44, 46-51.

Axtell, R. L., J. M. Epstein, J. S. Dean, G. J. Gumerman, A. C. Swedlund, J. Harburger, S. Chakravarty, R. Hammond, J. Parker, and M. Parker (2002), Population growth and collapse in a multiagent model of the Kayenta Anasazi in Long House Valley, Proc. Natl. Acad. Sci. U. S. A., 99, 7275-7279.

Beadle, N. C. W. (1948), The Vegetation and Pasture of Western New South Wales With Special Reference to Soil Erosion, Government Printer, Sydney.

Belnap, J., and D. A. Gillette (1998), Vulnerability of desert biological soil crusts to wind erosion: The influences of crust development, soil texture, and disturbance, J. Arid Environ., 39(2), 133-142.

Bengtsson, L., K. I. Hodges, and E. Roeckner (2006), Storm tracks and climate change, J. Clim., 19, 3518-3543.

Bowler, J. M., H. Johnston, J. M. Olley, J. R. Prescott, R. G. Roberts, W. Shawcross, and N. A. Spooner (2003), New ages for human occupation and climatic change at Lake Mungo, Australia, Nature, 42 1(6925), 837-840.

Brännvall, M., R. Binnderl, and I. Renberg (1999), The Medieval metal industry was the cradle of modern large-scale atmospheric lead pollution in northern Europe, Environ. Sci. Technol., 33, 4391-4395.

Brown, L. R. (1991), The global competition for land, J. Soil Water Conserv., 46, 394-397.

Bullard, J. E., S. P. Harrison, M. C. Baddock, N. Drake, T. E. Gill, G. McTainsh, and Y. Sun (2011), Preferential dust sources: A geomorphological classification designed for use in global dust-cycle models, J. Geophys. Res., 116, F04034, doi:10.1029/2011JF002061.

Cai, W., P. van Rensch, T. Cowan, and A. Sullivan (2010), Asymmetry in ENSO teleconnection with regional rainfall, its multidecadal variability, and impact, J. Clim., 23(18), $4944-4955$.

Chassemi, F., A. J. Jakeman, and H. A. Nix (1995), Salinisation of Land and Water Resources: Human Causes, Extent, Management and Case Studies, 526 pp., Univ. New South Wales Press Ltd, Canberra.

Chiaradia, M., B. E. Chenhall, A. M. Depers, B. L. Gulson, and B. G. Jones (1997), Identification of historical lead sources in roof dusts and recent lake sediments from an industrialized area: Indications from lead isotopes, Sci. Total Environ., 205(2-3), 107-128.

Chow, T. J., and C. C. Patterson (1961), The occurrence and significance of lead isotopes in pelagic sediments, Geochim. Cosmochim. Acta, 26(2), 263-308.

Condon, D. (2002), Out of the West: Historical Perspectives on the Western Division of New South Wales, 448 pp., Rangeland Management Action Plan, Mildura.

Condon, R. W., and M. E. Stannard (1957), Erosion in western New South Wales. Part 11. Forms of wind erosion, J. Soil Conserv. N. S. W., 13, 17-26.

Connor, S. E., and I. Thomas (2003), Sediments as archives of industrialisation: Evidence of atmospheric pollution in coastal wetlands of southern Sydney, Australia, Water Air Soil Pollut., 149(1-4), 189-210.
Cooke, C. A., P. H. Balcom, H. Bieser, and A. P. Wolfe (2009), Over three millennia of mercury pollution in the Peruvian Andes, Proc. Natl. Acad. Sci. U. S. A., 106(22), 8830-8834.

Costin, A. B. (1972), Carbon-14 dates from the Snowy Mountains area, southeastern Australia, and their interpretation, Quat. Res., 2, 579-590.

Crutzen, P. J. (2002), Geology of mankind, Nature, 415(23), 23.

Donald, C. M. (1967), Innovation in agriculture, in Agriculture in the Australian Economy, edited by D. B. Williams, pp. 57-86, Sydney Univ. Press, Sydney.

Dosseto, A., S. P. Turner, and J. Chappell (2008), The evolution of weathering profiles through time: New insights from uranium-series isotopes, Earth Planet. Sci. Lett., 274(3-4), 359-371.

Eggins, S. M., J. D. Woodhead, L. P. J. Kinsley, G. E. Mortimer, M. T. Slyvester, M. T. McCulloch, J. M. Hergt, and M. R. Handler (1997), A simple method for the precise determination of $>40$ trace elements in geological samples by ICPMS using enriched isotope internal standardisation, Chem. Geol., 134, 311-326.

Fanning, P. C. (1999), Recent landscape history in arid western New South Wales, Australia: A model for regional change, Geomorphology, 29(3-4), 191-209.

Fifield, L. K., R. J. Wasson, B. Pillans, and J. O. H. Stone (2010), The longevity of hillslope soil in SE and NW Australia, Catena, 81(1), 32-42.

Fister, W., and J. B. Ries (2009), Wind erosion in the central Ebro Basin under changing land use management. Field experiments with a portable wind tunnel, J. Arid Environ., 73(11), 996-1004.

Foley, J. A., et al. (2005), Global consequences of land use, Science, 309(5734), 570-574.

Forster, P., et al. (2007), Changes in atmospheric constituents and in radiative forcing, in Climate Change 2007: The Physical Science Basis. Contribution of Working Group I to the Fourth Assessment Report of the Intergovernmental Panel on Climate Change, edited by S. Solomon et al., pp. 129-234, Cambridge Univ. Press, Cambridge, United Kingdom and New York, N.Y., USA.

Frederiksen, J. S., and C. S. Frederiksen (2007), Interdecadal changes in Southern Hemisphere winter storm track modes, Tellus, Ser. A, 59(5), 599-617.

Fujiwara, F., M. Dos Santos, J. Marrero, G. Polla, D. Gomez, L. Dawidowskia, and P. Smichowski (2006), Fractionation of eleven elements by chemical bonding from airborne particulate matter collected in an industrial city in Argentina, J. Environ. Monit., 8(9), 913-922.

Gabrielli, P., et al. (2010), A major glacial-interglacial change in aeolian dust composition inferred from rare earth elements in Antarctic ice, Quat. Sci. Rev., 29(1-2), 265-273.

Gell, P., J. Fluin, J. Tibby, G. Hancock, J. Harrison, A. Zawadzki, D. Haynes, S. Khanum, F. Little, and B. Walsh (2009), Anthropogenic acceleration of sediment accretion in lowland floodplain wetlands, Murray-Darling Basin, Australia, Geomorphology, 108(1-2), 122-126.

Gergis, J., A. J. E. Gallant, K. Braganza, D. J. Karoly, A. Kathryn, L. Cullen, R. D'Arrigo, I. Goodwin, P. Grierson, and S. McGregor (2012), On the long-term context of the 1997-2009 "Big Dry" in southeastern Australia: Insights from a 206-year multi-proxy rainfall reconstruction, Clim. Change, 111, 923-944.

Goudie, A. S. (1978), Dust storms and their geomorphological implications, J. Arid Environ., 1, 291-310.

Goudie, A. S., and N. J. Middleton (2006), Desert Dust in the Global System, 283 pp., Springer, Berlin, Heidelberg, New York.

Han, J. S., K. J. Moon, J. Y. Ahn, Y. D. Hong, Y. J. Kim, S. Y. Ryu, S. S. Cliff, and T. A. Cahill (2004), Characteristics of ion components and trace elements of fine particles at Gosan, Korea in spring time from 2001 to 2002, Environ. Monit. Assess., 92(1-3), 73-93.

Harrison, J., H. Heijnis, and G. Caprarelli (2003), Historical pollution variability from abandoned mine sites, greater blue mountains world heritage area, New South Wales, Australia, Environ. Geol., 43, 680-687.

Heimsath, A. M., J. Chappell, W. E. Dietrich, K. Nishiizumi, and R. C. Finkel (2000), Soil production on a retreating escarpment in southeastern Australia, Geology, 28(9), 787-790.

Hendy, E. J., M. K. Gagan, C. A. Alibert, M. T. McCulloch, J. M. Lough, and P. J. Isdale (2002), Abrupt decrease in tropical Pacific Sea surface salinity at end of Little Ice Age, Science, 295(5559), 1511-1514.

Henzell, T. (Ed) (2007), Australian Agriculture: Its History and Challenges, pp. 308, CSIRO, Collingwood, VIC, Australia.

Hewawasam, T., F. Von Blanckenburg, M. Schaller, and W. Kubik (2003), Increase of human over natural erosion rates in tropical highlands constrained by cosmogenic nuclides, Geology, 31, 597-600.

Hong, S., J. P. Candelone, M. Soutif, and C. F. Boutron (1996), A reconstruction of changes in copper production and copper emissions to the atmosphere during the past 7000 years, Sci. Total Environ., 188(2-3), 183-193.

Jones, R. (1969), Fire-stick farming, Aust. Nat. Hist., 16, 224-228.

Kamber, B. S. (2009), Geochemical fingerprinting: 40 years of analytical development and real world applications, Appl. Geochem., 24, 1074-1086. 
Kamber, B. S., A. Greig, and K. D. Collerson (2005), A new estimate for the composition of weathered young upper continental crust from alluvial sediments, Queensland, Australia, Geochim. Cosmochim. Acta, 69(4), 1041-1058.

Kinoshita, N., et al. (2011), Assessment of individual radionuclide distributions from the Fukushima nuclear accident covering central-east Japan, Proc. Natl. Acad. Sci. U. S. A., 108(49), 19,526-19,529.

Lal, R. (2007), Evolution of the plow over 10,000 years and the rationale for no-till farming, Soil Till. Res., 93, 1-12.

Lal, R. (2010), Soil erosion impact on agronomic productivity and environment quality, Crit. Rev. Plant Sci., 17(4), 319-464.

Lamb, P. J., L. M. Leslie, R. P. Timmer, and M. S. Speer (2009), Multidecadal variability of eastern Australian dust and northern New Zealand sunshine: Associations with Pacific climate system, J. Geophys. Res., 114, D09106, doi:10.1029/2008JD011184.

Lavin, K. S., K. J. Hageman, S. K. Marx, P. W. Dillingham, and B. S. Kamber (2012), Using trace elements in particulate matter to identify the sources of semi-volatile organic contaminants in air at an alpine site, Environ. Sci. Technol., 46, 268-276.

Le Roux, G., D. Weiss, J. Grattan, N. Givelet, M. Krachler, A. Cheburkin, N. Rausch, B. Kobera, and W. Shotyk (2004), Identifying the sources and timing of ancient and medieval atmospheric lead pollution in England using a peat profile from Lindow bog, Manchester, J. Environ. Monit., 6, 502-510.

Le Roux, G., N. Fagel, F. De Vleeschouwer, M. Krachler, V. Debaille, P. Stille, N. Mattielli, W. O. van der Knaap, J. F. van Leeuwen, and W. Shotyk (2012), Volcano- and climate-driven changes in atmospheric dust sources and fluxes since the Late Glacial in central Europe, Geology, 40(4), 335-338.

Leblanc, M., T. Tweed, A. Van Dijk, and B. Timbal (2012), A review of historic and future hydrological changes in the Murray-Darling Basin, Global Planet. Change, 80-81, 226-248.

Leblanc, M. J., P. Tregoning, G. Ramillien, S. O. Tweed, and A. Fakes (2009), Basin-scale, integrated observations of the early 21 st century multiyear drought in southeast Australia, Water Resour. Res., 45, W04408, doi:10.1029/2008WR007333.

Lee, C. S. L., S. H. Qi, G. Zhang, C. L. Luo, L. Y. L. Zhao, and X. D. Li (2008), Seven thousand years of records on the mining and utilization of metals from lake sediments in central China, Environ. Sci. Technol. 42(13), 4732-4738.

Lejju, B. J., D. Taylor, and P. Robertshaw (2005), Late-Holocene environmental variability at Munsa archaeological site, Uganda: A multicore, multiproxy approach, Holocene, 15(7), 1044-1061.

Leys, J. (1999), Wind erosion on agricultural land, in Aeolian Environments, Sediments and Landforms, edited by A. S. Goudie, I. Livingstone, and S. Stokes, pp. 143-166, John Wiley, Ltd, Chichester.

Little, I. P., and W. T. Ward (1981), Chemical and mineralogical trends in a chronosequence developed in alluvium in eastern Victoria, Australia Geoderma, 25, 173-188.

Lomax, J., A. Hilgers, and U. Radtke (2011), Palaeoenvironmental change recorded in the palaeodunefields of the western Murray Basin, South Australia-New data from single grain OSL-dating, Quat. Sci. Rev., 30(5-6), 723-736

Lopez, M. V., M. Sabre, A. Gracia, J. L. Arrue, and L. Gomes (1998), Tillage effects on soil surface conditions and dust emission by wind erosion in semiarid Aragon NE Spain, Soil Till. Res., 45, 91-105.

Lough, J. M. (2011), Great Barrier Reef coral luminescence reveals rainfall variability over northeastern Australia since the 17th century, Paleoceanography, 26, PA2201, doi:10.1029/2010PA002050.

Manning, M. R., and W. H. Melhuish (1994), Delta ${ }^{14} \mathrm{CO}_{2}$ records from Wellington, in Trends 93-A Compendium of Data on Global Change and Online Updates, edited by T. A. Boden et al., pp. 143-202, Carbon Dioxide Information Analysis Centre, Oak Ridge National Laboratory, Oak Ridge, Tenn., USA.

Martin, A. R. H. (1999), Pollen analysis of Digger's Creek Bog, Kosciuszko National Park: Vegetation history and tree-line change, Aust. J. Bot., 47 , 725-744.

Martin, C. H., A. J. Hargraves, R. J. Kininmonth, and S. M. C. Saywell (1993), History of Coal Mining in Australia, 247 pp., The Australian Institute of Mining and Metallurgy, Sydney.

Marx, S. K., and B. S. Kamber (2010), High-precision trace-element systematics of sediments in the Murray-Darling Basin, Australia: Sediment tracing and palaeo-climate implications of fine scale chemical heterogeneity of the upper continental crust, Appl. Geochem., 25, 1221-1237.

Marx, S. K., B. S. Kamber, and H. A. McGowan (2005a), Provenance of long travelled dust determined with ultra-trace-element composition: A pilot study with samples from New Zealand glaciers, Earth Surf. Processes Landforms, 30, 699-716.

Marx, S. K., B. S. Kamber, and H. A. McGowan (2005b), Estimates of Australian dust flux into New Zealand: Quantifying the eastern
Australian dust plume pathway using trace element calibrated ${ }^{210} \mathrm{~Pb}$ as a monitor, Earth Planet. Sci. Lett., 239, 336-351.

Marx, S. K., B. S. Kamber, and H. A. McGowan (2008), Scavenging of trace metal pollutants by mineral dust: Inter-regional transport of trace metal pollution to New Zealand, Atmos. Environ., 42(10), 2460-2478.

Marx, S. K., H. A. McGowan, and B. S. Kamber (2009), Long-range dust transport from eastern Australia: A proxy for Holocene aridity and ENSO-induced climate variability, Earth Planet. Sci. Lett., 282, 167-177.

Marx, S. K., B. S. Kamber, H. A. McGowan, and A. Zawadzki (2010), Atmospheric pollutants in alpine peat bogs record a detailed chronology of industrial and agricultural development on the Australian continent, Environ. Pollut., 158, 1615-1628.

Marx, S. K., B. S. Kamber, H. A. McGowan, and J. Denholm (2011), Holocene dust deposition rates in Australia's Murray-Darling Basin record the interplay between aridity and the position of the mid-latitude westerlies, Quat. Sci. Rev., 30, 3290-3305.

McAlpine, C. A., J. Syktus, R. C. Deo, H. A. McGowan, S. Phinn, and P. Lawrence (2007), Modeling the impact of anthropogenic land cover change on Australia's regional climate, Geophys. Res. Lett., 34, L22711, doi:10.1029/2007GL031524.

McAlpine, C. A., J. Syktus, R. C. Deo, J. G. Ryan, G. M. McKeon, H. A. McGowan, and S. R. Phinn (2009), A continent under stress: Interactions, feedbacks and risks associated with impact of modified land cover on Australia's climate, Global Change Biol., 15, 2206-2223.

McConnell, J. R., and R. Edwards (2008), Coal burning leaves toxic heavy metal legacy in the Arctic, Proc. Natl. Acad. Sci. U. S. A., 105(34), $12,140-12,144$.

McConnell, J. R., A. J. Aristarain, J. R. Banta, P. R. Edwards, and J. C. Simões (2007), 20th-Century doubling in dust archived in an Antarctic Peninsula ice core parallels climate change and desertification in South America, Proc. Natl. Acad. Sci. U. S. A., 104(14), 5743-5748.

McCormac, F. G., A. G. Hogg, P. G. Blackwell, C. E. Buck, T. F. G. Higham, and P. J. Reimer (2004), SHCal04 Southern Hemisphere calibration, 0-11.0 cal kyr BP, Radiocarbon, 46(3), 1087-1092.

McDonald, G. T., and T. J. Hundloe (1993), Policies for a sustainable future, in Land Degradation Processes in Australia, edited by G. H. McTainsh and C. Boughton, pp. 345-383, Longman Cheshire Pty Limited, Melbourne.

McGarity, J. W., and R. R. Storrier (1986), Fertilizers, in Australian Soils: The Human Impact, edited by J. S. Russell and R. F. Isbell, pp. 304-333, Univ. Queensland Press, Brisbane.

McGowan, H. A., S. K. Marx, J. Soderholm, B. S. Kamber, and J. Denholm (2009), Reconstructing annual inflows to the headwater catchments of the Murray River, Australia, using the Pacific Decadal Oscillation, Geophys. Res. Lett., 36, L06707, doi:10.1029/2008GL037049.

McKeon, G., W. Hall, B. Henry, G. Stone, and I. Watson (2004), Pasture Degradation and Recovery in Australia's Rangelands, 256 pp., Natural Resource Sciences, Queensland Department of Natural Resources Mines and Energy, Brisbane.

McMichael, C. H., M. B. Bush, D. R. Piperno, M. R. Silman, A. R. Zimmerman, and C. Anderson (2012), Spatial and temporal scales of pre-Columbian disturbance associated with western Amazonian lakes Holocene, 22(2), 131-141.

McTainsh, G. H. (1989), Quaternary aeolian dust processes and sediments in the Australian region, Quat. Sci. Rev., 8(3), 235-253.

McTainsh, G. H., and J. F. Leys (1993), Soil erosion by wind, in Land Degredation Processes in Australia, edited by G. H. McTainsh and W. C. Boughton, pp. 188-230, Longman Cheshire Pty Ltd, Melbourne.

McTainsh, G. H., R. Burgess, and J. R. Pitblado (1989), Aridity, drought and dust storms in Australia (1960-84), J. Arid Environ., 16(1), 11-22.

McTainsh, G. H., A. W. Lynch, and E. K. Tews (1998), Climatic controls upon dust storm occurrence in eastern Australia, J. Arid Environ., 39(3), $457-466$.

McTainsh, G. H., Y. Chan, H. A. McGowan, J. F. Leys, and K. Tews (2005), The 23rd October, 2002 dust storm in eastern Australia: Characteristics and meteorological conditions, Atmos. Environ., 39, 1227-1236.

McTainsh, G. H., J. Leys, T. O’Loingsigh, and C. Strong (2011), Wind erosion and land management in Australia during 1940-1949 and 2000-2009, report prepared for the Australian Government Department of Sustainability, Environment, Water, Population and Communities on behalf of the 2011 State of the Environment Committee, DSEWPaC, Canberra.

Montgomery, D. R. (2007a), Dirt: The Erosion of Civilizations, 285 pp. Univ. California Press Ltd, Berkeley and Los Angeles.

Montgomery, D. R. (2007b), Soil erosion and agricultural sustainability, Proc. Natl. Acad. Sci. U. S. A., 104(33), 13,268-13,272.

Mooney, S. D., et al. (2011), Late Quaternary fire regimes of Australasia, Ouat. Sci. Rev., 30(1-2), 28-46.

Mudd, G. M. (2007), An analysis of historic production trends in Australian base metal mining, Ore Geol. Rev., 32, 227-261.

Mulitza, S., et al. (2010), Increase in African dust flux at the onset of commercial agriculture in the Sahel region, Nature, 466(7303), 226-228. 
Murphy, B. F., and B. Timbal (2008), A review of recent climate variability and climate change in southeastern Australia, Int. J. Climatol., 28(7), 859-879.

Neff, J. C., A. P. Ballantyne, G. L. Farmer, N. M. Mahowald, J. L. Conroy, C. C. Landry, J. T. Overpeck, T. H. Painter, C. R. Lawrence, and R. L. Reynolds (2008), Increasing eolian dust deposition in the western United States linked to human activity, Nat. Geosci., 1, 189-195.

Nordstrom, K. F., and S. Hotta (2004), Wind erosion from cropland in the USA: A review of problems, solutions and prospects, Geoderma, 121(3-4), 157-167.

O'Gorman, E. (2013), Growing rice on the Murrumbidgee River: Cultures, politics, and practices of food production and water use, 1900 to 2012 , J. Aust. Stud., 37, 96-115.

Olley, J. M., and R. J. Wasson (2003), Changes in the flux of sediment in the Upper Murrumbidgee catchment, southeastern Australia, since European settlement, Hydrol. Processes, 17(16), 3307-3320.

Osterberg, E., et al. (2008), Ice core record of rising lead pollution in the North Pacific atmosphere, Geophys. Res. Lett., 35, L05810, doi:10.1029/ 2007GL032680.

Pacyna, J. M., and E. G. Pacyna (2001), An assessment of global and regional emissions of trace metals to the atmosphere from anthropogenic sources worldwide, Environ. Rev., 9, 269-298.

Pearson, M., and J. Lennon (2010), Pastrol Australia, Fortunes, Failures and Hard Yakka: A Historical Overview 1788-1967, CSIRO, Melbourne.

Peck, A. J. (1993), Salinty, in Land Degradation Processes in Australia, edited by G. H. McTainsh and W. C. Broughton, pp. 234-268, Longman Cheshire Pty Ltd, Melbourne.

Pimentel, D., et al. (1995), Environmental and economic costs of soil erosion and conservation benefits, Science, 267, 1117-1123.

Pye, K. (1987), Aeolian Dust and Dust Deposits, 334 pp., Academic Press Inc, London.

Rasmussen, M., et al. (2011), An aboriginal Australian genome reveals separate human dispersals into Asia, Science, 334(6052), 94-98.

Rauch, J., and J. Pacyna (2009), Earth's global Ag, Al, Cr, Cu, Fe, Ni, Pb, and $\mathrm{Zn}$ cycles, Global Biogeochem. Cycles, 23, GB2001, doi:10.1029/ 2008GB003376.

Rimmington, G. M., and N. Nicholls (1993), Forecasting wheat yields in Australia with the Southern Oscillation Index, Aust. J. Agric. Res., 44, 625-632.

Ringrose-Voase, A. J., D. W. Rhodes, and G. F. Hall (1989), Reclamation of a scalded, red duplex soil by waterponding, Aust. J. Soil Res., 27, 779-795.

Roberts, R. G., R. Jones, N. A. Spooner, M. J. Head, A. S. Murray, and M. A. Smith (1994), The human colonisation of Australia: Optical dates of 53,000 and 60,000 years bracket human arrival at Deaf Adder Gorge, Northern Territory, Quat. Sci. Rev., 13(5-7), 575-583.

Rose, C. W., and R. C. Dalal (1998), Erosion and runoff of nitrogen, paper presented at Proceeding of the Symposium on Advances in Nitrogen Cycling in Agricultural Ecosystems, CAB Intl., Wallingford, U.K., Brisbane, Australia, May 11-15.

Seidel, D. J., Q. Fu, W. J. Randel, and T. J. Reichler (2008), Widening of the tropical belt in a changing climate, Nat. Geosci., 1(1), 21-24.

Shao, Y., K.-H. Wyrwoll, A. Chappell, J. Huang, Z. Lin, G. H. McTainsh, M. Mikami, T. Y. Tanaka, X. Wang, and S. Yoon (2011), Dust cycle: An emerging core theme in Earth system science, Aeolian Res., 2(4), 181-204.

Shen, Y., Z. Shen, M. Du, and W. Wang (2005), Dust emission over different land surface in the arid region of northwest China, J. Meteorol. Soc. Jpn., 83(6), 935-942.

Shotyk, W. (2002), The chronology of anthropogenic, atmospheric Pb deposition recorded by peat cores in three minerogenic peat deposits from Switzerland, Sci. Total Environ., 292, 19-31.

Shotyk, W., D. Weiss, P. G. Appleby, A. Cheburkin, M. Gloor, J. D. Kramers, S. Reese, and W. O. Van Der Knaap (1998), History of atmospheric lead deposition since $12,37014 \mathrm{C}$ yr BP from a peat bog, Jura Mountains, Switzerland, Science, 281, 1635-1640.

Shotyk, W., D. Weiss, J. D. Kramers, R. Frei, A. K. Cheburkin, M. Gloor, and S. Reese (2001), Geochemistry of the peat bog at Etang de la Gruere, Jura Mountains, Switzerland, and its record of atmospheric $\mathrm{Pb}$ and lithogenic trace metals (Sc, Ti, Y, Zr, and REE) since 12,370C-14 yr BP, Geochim. Cosmochim. Acta, 65(14), 2337-2360.

Steffen, W., et al. (2004), Global Change and the Earth System: A Planet Under Pressure, Springer-Verlag, Berlin, Heidelberg, New York.

Suresh, P. O., A. Dosseto, P. P. Hesse, and H. Handley (2013), Soil formation rates determined from uranium-series isotope disequilibria in soil profiles from the southeastern Australian highlands, Earth Planet. Sci. Lett., 379, 26-37.

Taylor, M. P., A. K. Mackay, K. A. Hudson-Edwards, and E. Holz (2010), Soil $\mathrm{Cd}, \mathrm{Cu}, \mathrm{Pb}$ and $\mathrm{Zn}$ contaminants around Mount Isa city, Queensland, Australia: Potential sources and risks to human health, Appl. Geochem., 25(6), 841-855.

Thompson, D. W. J., and S. Solomon (2002), Interpretation of recent Southern Hemisphere climate change, Science, 296(5569), 895-899.

Twidale, C. R., J. A. Bourne, N. A. Spooner, and E. J. Rhodes (2007), The age of the palaeodunefield of the northern Murray Basin in South Australia: Preliminary results, Quat. Int., 166(1), 42-48.

Vallelonga, P., et al. (2010), Lead isotopic compositions in the EPICA Dome $\mathrm{C}$ ice core and Southern Hemisphere Potential Source Areas, Quat. Sci. Rev., 29(1-2), 247-255.

van der Kaars, W. A. (1991), Palynology of eastern Indonesian marine pistoncores: A late quaternary vegetational and climatic record for Australasia, Palaeogeogr. Palaeoclimatol. Palaeoecol., 85(3-4), 239-302.

Verdon, D. C., and S. W. Franks (2006), Long-term behaviour of ENSO: Interactions with the PDO over the past 400 years inferred from paleoclimate records, Geophys. Res. Lett., 33, L06712, doi:10.1029/ 2005 GL025052.

Verdon-Kidd, D. C., and A. S. Kiem (2009), Nature and causes of protracted droughts in southeast Australia: Comparison between the Federation, WWII, and Big Dry droughts, Geophys. Res. Lett., 36, L22707, doi:10.1029/2009GL041067.

Walker, P. H., and R. J. Coventry (1976), Soil profile development in some alluvial deposits of eastern New South Wales, Aust. J. Soil Res., 14(305-317)

Walling, D. E., Q. He, and P. G. Appleby (2002), Conversion models for use in soil-erosion, soil-redistribution and sedimentation investigations, in Handbook for the Assessment of Soil Erosion and Sediment Using Environmental Radionuclides, edited by F. Zapata, pp. 111-164, Kluwer Academic Publishers, Vienna.

Wasson, R. J., and R. W. Galloway (1986), Sediment yield in the barrier range before and after European settlement, Aust. Rangelands J., 8(2), 79-80.

Webb, N. P., and C. L. Strong (2011), Soil erodibility dynamics and its representation for wind erosion and dust emission models, Aeolian Res., 3 , $165-179$.

Webb, N. P., H. A. McGowan, S. R. Phinn, and G. H. McTainsh (2006), AUSLEM (Australian land erodibility model): A tool for identifying wind erosion in Australia, Geomorphology, 78, 179-200.

Webb, N. P., H. A. McGowan, S. R. Phinn, G. H. McTainsh, and J. F. Leys (2009), Simulation of the spatiotemporal aspects of land erodibility in the northeast Lake Eyre Basin, Australia, 1980-2006, J. Geophys. Res., 114, F01013, doi:10.1029/2008JF001097.

Weng, Z., G. M. Mudd, T. Martin, and C. A. Boyle (2012), Pollutant loads from coal mining in Australia: Discerning trends from the Nationa Pollutant Inventory (NPI), Environ. Sci. Policy, 19-20, 78-89.

Wolfe, A. P., et al. (2013), Stratigraphic expressions of the HoloceneAnthropocene transition revealed in sediments from remote lakes, Earth Sci. Rev., 116(1), 17-34. 